\title{
Review Article \\ The Role of Earthworms in Tropics with Emphasis on Indian Ecosystems
}

\author{
Radha D. Kale ${ }^{1}$ and Natchimuthu Karmegam ${ }^{2}$ \\ ${ }^{1}$ Centre for Scientific Research and Advanced Learning, Mount Carmel College, Bangalore, Karnataka 560 052, India \\ ${ }^{2}$ Department of Biotechnology, VMKV Engineering College, Vinayaka Missions University, Periya Seeragapadi, \\ Salem, Tamil Nadu 636 308, India
}

Correspondence should be addressed to Natchimuthu Karmegam, kanishkarmegam@gmail.com

Received 3 November 2009; Accepted 16 December 2009

Academic Editor: Thilagavathy Daniel

Copyright (c) 2010 R. D. Kale and N. Karmegam. This is an open access article distributed under the Creative Commons Attribution License, which permits unrestricted use, distribution, and reproduction in any medium, provided the original work is properly cited.

\begin{abstract}
The paper highlights the research carried out by different scientists in India on aspects of earthworm population dynamics and species diversity, associated with other soil fauna and microflora. It also deals with the importance of earthworm activity on physicochemical properties of soil with reference to India and other tropical countries. Stress is laid on the earthworm plant association and importance of the secretions of earthworms as plant growth stimulators. Moreover, the earthworm species reported and being utilized for vermicomposting in India are discussed, since vermicomposting is the ultimate technology which renders for the improvement of soil fertility status and plant growth. Earthworms serve as indicators of soil status such as the level of contamination of pollutants: agrochemicals, heavy metals, toxic substances, and industrial effluents; human-induced activities: land-management practices and forest degradation. In all these fields there is lacuna with respect to contributions from India when compared to the available information from other tropical countries. There is lot of scope in the field of research on earthworms to unravel the importance of these major soil macrofauna from holistic ecological studies to the molecular level.
\end{abstract}

\section{Introduction}

Earthworms belonging to Phylum Annelida, Class Chaetopoda, and Order Oligochaeta occupy a unique position in animal kingdom. They are the first group of multicellular, eucoelomate invertebrates who have succeeded to inhabit terrestrial environment. They form major soil macrofauna. Their species richness, abundance, and distribution pattern reflect on edaphic and climatic factors of the geographical zone. They serve as "bioindicators" to understand the physicochemical characteristics of their habitat. Their horizontal and vertical stratification and abundance contribute to pedogenesis and soil profile. Encouraging their establishment through no tillage or shallow ploughing and enriching soil with organic matter incorporation has resulted in improving soil fertility. This has been experimented for several decades at Rothamsted Research Station, U.K. The interaction of earthworms and other microflora and fauna has given much scope for understanding of soil community and its influence on above ground primary production.
Distinctive habitat, food niches, and adaptive mechanisms of earthworms have opened up new fields for investigations on their role in organic waste management. One of the advantageous factors in this field is the use of earthworms to minimize the degradable organic matter and to use the same as bioresource for organic manure production. The manure produced serves as good source of soil amendment. The ecologically distinguished epigeic earthworms are used for producing the organic manure, "vermicompost". This has gained attention of garden lovers, agriculturists, and agroindustries to convert organic matter generated at different levels into rich, odorless, free flowing compost to support sustainable agriculture.

\section{Earthworms: Components of Soil Biota}

Earthworms form one of the major macrofauna among soil biota to maintain dynamic equilibrium and regulate soil fertility. Their existence depends on adequate moisture, soil 
texture, $\mathrm{pH}$, electrolyte concentration, and food source in the given ecosystem. This clearly indicates the interdependency of the environmental factors to the survival of earthworms; when such conditions are created, they further contribute to soil fertility through their activity.

\section{Food Niches of Earthworms}

Degradation of leaf material commences from the time it detaches itself from the plant and drops to ground to add to litter. Earthworms are the major secondary decomposers in the soil faunal community. They feed on decomposed organic material at different levels of degradation. Lee [1] has suggested that earthworms survive on microorganisms, micro- and mesofauna associated with ingested dead tissue. According to him, earthworms that feed near the surface on decomposing litter and at the root zone on dead roots are the detritivores and those remain at subsurface and consume large quantities of soil are geophagous earthworms.

Lavelle [2] has categorized geophagous earthworms as polyhumic, oligohumic, and mesohumic based on the proportion of humus and soil in their feed. Through factorial analysis, he has given the explanation that temperature differences with latitude and litter characteristics like quantity and decomposability determine the variations observed with reference to their distribution. The detritivorous epigeic earthworms form the major component of earthworm fauna in temperate regions and mesohumic endogeic earthworms are predominant in tropical forests. There is minimum representation of mesohumic earthworms in temperate regions. Oligohumic earthworms that feed on soil having very low level of organic matter are abundant only in tropical regions.

Lavelle [2] considers polyhumic earthworms as more stable fraction of earthworm community occupying different soil strata as topsoil feeders to species of rhizosphere in tropical regions. Thus, tropical earthworms depend more on soil mixed with different levels of humic substances rather than surface litter. More stable environments like heavy rainfall areas (2000 to above $4000 \mathrm{~mm}$ rain/annum) in the state of Karnataka, India, have greater diversity of earthworms than the dry areas (<600 to $900 \mathrm{~mm}$ rain/annum). The geophagous earthworms of mesohumic and polyhumic types are widely distributed in places receiving heavy rainfall in this subtropical part of the country (Tables 1 and 2).

The acceptance level of various leaf litters shows positive correlation to nitrogen and carbohydrate contents and negative correlation to polyphenol content [3]. Ganihar [4] studied the litter feeding of Pontoscolex corethrurus in a multiple-choice test. He found variations in degree of acceptability of different litter that showed positive correlations to levels of organic carbon and nitrogen content. The least preference for Eucalyptus camaldulensis and Acacia auriculiformis was linked with high levels of polyphenols. It has been shown that Lampito mauritii exhibited similar preference either for partially decomposed large pieces of leaf material of different types or for powdered leaves mixed with agar base [5]. It could be inferred that apart from physical nature of leaf matter, chemical compounds in them serve as attractants or repellants (Tables 3 and 4). Ganihar [4] is of the view that in land reclamation sites, if earthworms have to be introduced, it is essential to develop above ground plant community. Litter from such plants when mixes with soil, at different levels of decomposition, serves as feed to developing earthworm population. The available carbon source encourages population growth of earthworms [6]. In India, Lampito mauritii is the most widely distributed earthworm in different agro-ecosystems [7-12]. This earthworm preferred decomposing grass of paddy (Oryza sativa) and finger millet (Eleucine coracana) to other leaf litter [5]. The grasses when developed in reclamation sites can form an ideal base for establishment of Lampito mauritii to bring about improvement in soil structure and finally chemical and biological activities. Food preference and sensitivity to other edaphic factors determine the possibility of introduction of earthworms for land reclamation.

\section{Earthworm Activity on Physicochemical Properties of Soil}

Earthworms are the major macrofauna in the soil community. They are distributed at different depths in soil strata. The litter feeders, which are not burrowers, constitute a very small number in tropical situations. The burrowing endogeic earthworms live in horizontal and vertical burrows constructed in soil strata. They make these burrows partly by ingesting soil particles through their way and partly by pushing the soil to the sides [13]. The ingested soil along with organic matter passes through the gut and undigested matter is released at the opening of the burrow on soil surface or at the subsurface as castings. The subsurface castings contribute to soil profile [1].

The burrows of earthworms, which run horizontally or vertically depending on burrow forming ability of species, will determine the possible physical effects on soil characteristics. In temperate regions where deep burrowing anecic earthworms are of common occurrence, it is opined that infiltrations can bring about leaching of nutrients from soils to ground water. The leachate volume may show an increase of four to twelve folds due to their activity [14]. Introduction of Aporrectodea caliginosa into coniferous forest soils resulted in fifty fold increase in concentration of nitrate and cations in soil solution. But the amount that entered ground water or plant system remained undetermined [15]. One of the major contributions of burrowing activity of earthworms is in affecting soil porosity $[16,17]$. The major impact on hydrology has been worked out with respect to activity of anecic earthworm Lumbricus terrestris [18]. Information is lacking in India with respect to burrows of earthworms, their structure, and any variations observed depending on soil type. Influence of organic matter, agricultural practices on earthworm population, and similarly the role of earthworms in modifying the situations in cultivable lands are very meager in a country having diversity and abundance of the populations in different agro-ecosystems. Reddy et al. [19] reported the influence of various management practices 
TABLE 1: Earthworm distribution in Southern Karnataka (India) in different agroclimatic zones including coastal plains, hilly regions, and interior plains.

\begin{tabular}{|c|c|c|c|c|c|c|}
\hline Sl. No. & Species & Moisture level (\%) & Soil type & $\begin{array}{l}\text { Vertical } \\
\text { distribution }(\mathrm{cm})\end{array}$ & Food niche & $\begin{array}{l}\text { Population } \\
\text { density } \\
\left(\text { no. } / 100 \mathrm{~m}^{2}\right)\end{array}$ \\
\hline 1 & $\begin{array}{l}\text { Curgeona } \\
\text { narayani }\end{array}$ & $\begin{array}{c}\text { Wet land-in waterlogged } \\
\text { soil }\end{array}$ & Red loamy soil & Up to 45 & Mesohumic & $640-11,250$ \\
\hline 2 & $\begin{array}{l}\text { Dichogaster } \\
\text { affinis }\end{array}$ & $20-40$ & $\begin{array}{l}\text { Red loamy, alluvial } \\
\text { and lateritic }\end{array}$ & $5-10$ & $\begin{array}{l}\text { Mesohumic } \\
\text { to polyhumic }\end{array}$ & $60-250$ \\
\hline 3 & D. bolaui & $20-40$ & $\prime \prime$ & $\prime \prime$ & $\prime \prime$ & $60-450$ \\
\hline 4 & D. curgensis & $20-40$ & Red loamy & $\prime \prime$ & Polyhumic & $25-200$ \\
\hline 5 & D. modigliani & $20-40$ & Red sandy & $\prime \prime$ & Mesohumic & $10-25$ \\
\hline 6 & D. saliens & $20-40$ & Red sandy & $\prime \prime$ & 11 & $65-265$ \\
\hline 7 & $\begin{array}{l}\text { Drawida } \\
\text { ampullacea }\end{array}$ & $>40$ & Red loamy & $10-20$ & Polyhumic & 275-930 \\
\hline 8 & D. barwelli & $>50$ & $\begin{array}{l}\text { Red loamy to sandy } \\
\text { soil }\end{array}$ & $10-30$ & $\prime \prime$ & $275-576$ \\
\hline 9 & $\begin{array}{l}\text { D. barwelli } \\
\text { impertusa }\end{array}$ & $>50$ & Red loamy & $\prime \prime$ & $\prime \prime$ & $120-430$ \\
\hline 10 & D. calebi & $>50$ & $\begin{array}{l}\text { Red loamy to sandy } \\
\text { soil }\end{array}$ & $10-30$ & Polyhumic & $80-1200$ \\
\hline 11 & D. ferina & $40-50$ & Red loamy & $20-30$ & Mesohumic & $40-340$ \\
\hline 12 & D. ghatensis & $40-50$ & $\prime \prime$ & $10-20$ & $\prime \prime$ & $450-1350$ \\
\hline 13 & D. kanarensis & $40-50$ & $\prime \prime$ & $\prime \prime$ & $\prime \prime$ & $85-400$ \\
\hline 14 & D. lennora & $40-50$ & Red sandy soil & $\prime \prime$ & $\prime \prime$ & $15-30$ \\
\hline 15 & D. modesta & $40-50$ & $\prime \prime$ & $10-30$ & $\prime \prime$ & $4-500$ \\
\hline 16 & D. paradoxa & $>40$ & Red loamy to alluvial & $10-20$ & Polyhumic & $1700-2500$ \\
\hline 17 & $\begin{array}{l}\text { D. pellucida } \\
\text { pallida }\end{array}$ & $>40$ & Lateritic to Red loamy & $\prime \prime$ & Mesohumic & $4-500$ \\
\hline 18 & D. scandens & $>40$ & Red sandy loam & $5-10$ & Polyhumic & $10-350$ \\
\hline 19 & D. sulcata & $>40$ & Alluvial soil & $10-30$ & Polyhumic & $65-235$ \\
\hline 20 & $\begin{array}{l}\text { Glyphidrillus } \\
\text { annandalei }\end{array}$ & $>40$ & $\begin{array}{l}\text { Sandy bed to Red } \\
\text { loam }\end{array}$ & $20-45$ & Oligohumic & $130-1600$ \\
\hline 21 & $\begin{array}{l}\text { Gordiodrilus } \\
\text { elegans }\end{array}$ & $>40$ & Red sandy loam & $10-40$ & Mesohumic & $24-200$ \\
\hline 22 & $\begin{array}{l}\text { Hoplochaetella } \\
\text { kempi }\end{array}$ & $30-40$ & Lateritic to alluvial & $10-30$ & Polyhumic & $10-430$ \\
\hline 23 & H. suctoria & $30-40$ & Alluvial & $10-20$ & $\prime \prime$ & $50-240$ \\
\hline 24 & $\begin{array}{l}\text { Hoplochaetella } \\
\text { sp. }\end{array}$ & $40-50$ & Red loam & $20-40$ & $\prime \prime$ & $460-3330$ \\
\hline 25 & Howascolex sp. & $30-40$ & Red loam & $10-30$ & $\prime \prime$ & $145-2500$ \\
\hline 26 & $\begin{array}{l}\text { Lampito } \\
\text { mauritii }\end{array}$ & $20-30$ & Red sandy to lateritic & $10-30$ & Mesohumic & $720-2190$ \\
\hline 27 & Mallehula indica & $30-40$ & Red loam & $10-20$ & Mesohumic & $180-880$ \\
\hline 28 & $\begin{array}{l}\text { Megascolex } \\
\text { filiciseta }\end{array}$ & $30-40$ & Lateritic & $5-10$ & Polyhumic & $15-330$ \\
\hline 29 & M. insignis & $30-40$ & Alluvial & $5-20$ & Polyhumic & $65-800$ \\
\hline 30 & M. lawsoni & $30-40$ & $\begin{array}{l}\text { Red loam to sandy } \\
\text { loam }\end{array}$ & $10-30$ & Mesohumic & $120-1000$ \\
\hline 31 & M. konkanensis & $30-40$ & Lateritic to alluvial & $20-45$ & Mesohumic & $20-3900$ \\
\hline 32 & $\begin{array}{l}\text { Metaphire } \\
\text { houlleti }\end{array}$ & $>40$ & Alluvial and Red loam & $10-40$ & Polyhumic & $18-2140$ \\
\hline 33 & $\begin{array}{l}\text { Octochaetona } \\
\text { albida }\end{array}$ & $30-40$ & Red loam & $10-20$ & Polyhumic & $150-650$ \\
\hline 34 & O. beatrix & $20-30$ & Sandy loam & $\prime \prime$ & $\prime \prime$ & $40-335$ \\
\hline 35 & O. rosea & $30-40$ & Alluvial & $10-20$ & Mesohumic & $15-120$ \\
\hline 36 & P. excavatus & $>40$ & Organic layer & $0-5$ & Detritivore & $18-8000$ \\
\hline 37 & Plutellus timidus & $30-40$ & Alluvial & $10-15$ & Mesohumic & $60-460$ \\
\hline 38 & $\begin{array}{l}\text { Polypheretima } \\
\text { elongata }\end{array}$ & $>40$ & $\begin{array}{l}\text { Sandy loam to Red } \\
\text { loam }\end{array}$ & $30-60$ & Mesohumic & $194-4000$ \\
\hline 39 & $\begin{array}{l}\text { Pontoscolex } \\
\text { corethrurus }\end{array}$ & $30-50$ & $\begin{array}{l}\text { Sandy, alluvial, loamy, } \\
\text { lateritic }\end{array}$ & $5-15$ & $\begin{array}{l}\text { Mesohumic } \\
\text { to polyhumic }\end{array}$ & $250-7100$ \\
\hline
\end{tabular}


TABLE 2: Habitat preference of widely distributed earthworm species Lampito mauritii and Pontoscolex corethrurus at study sites.

\begin{tabular}{|c|c|c|c|c|c|}
\hline District & $\begin{array}{l}\text { Agroclimatic } \\
\text { zone }\end{array}$ & $\begin{array}{l}\text { Mean annual } \\
\text { rainfall }(\mathrm{mm})\end{array}$ & Soil type & $\begin{array}{l}\text { Earthworm } \\
\text { species }\end{array}$ & Habitat preference \\
\hline Bangalore & Eastern dry zone & $700-900$ & Red loamy soil & $\begin{array}{l}\text { Lampito } \\
\text { mauritii }\end{array}$ & Arable lands \\
\hline Kolar & $\prime \prime$ & $600-800$ & $\begin{array}{l}\text { Lateritic and red } \\
\text { sandy soil }\end{array}$ & $\prime \prime$ & Grasslands \\
\hline Tumkur & $\prime \prime$ & $\prime \prime$ & Red sandy soil & $\prime \prime$ & $\begin{array}{l}\text { Grasslands and arable } \\
\text { lands }\end{array}$ \\
\hline Chickmagalur & $\begin{array}{l}\text { South transition } \\
\text { zone }\end{array}$ & $900-1000$ & Red loamy soil & $\begin{array}{l}\text { Species richness } \\
\text { than species } \\
\text { dominance }\end{array}$ & Varied habitats \\
\hline Chickmagalur & Hilly zone & $2000-3000$ & Red loamy soil & $\begin{array}{l}\text { Pontoscolex } \\
\text { corethrurus }\end{array}$ & Plantations \\
\hline Coorg & Hilly zone & $2000->4000$ & $\prime \prime$ & $\prime \prime$ & $\begin{array}{l}\text { Grasslands and } \\
\text { plantations }\end{array}$ \\
\hline South Kanara & Coastal zone & $3000>4000$ & Coastal alluvial soil & $\begin{array}{l}\text { P. corethrurus } \\
\text { and Megascolex } \\
\text { konkanensis }\end{array}$ & $\begin{array}{l}\text { Grasslands, } \\
\text { plantations, arable } \\
\text { lands }\end{array}$ \\
\hline
\end{tabular}

TABLE 3: Disintegration of different leaf matters due to selective feeding by earthworm Lampito mauritii [5].

\begin{tabular}{lccccccccc}
\hline Leaf matter & 1 & 2 & 3 & 4 & 5 & 6 & 7 & 8 & - \\
\hline Millet straw & 70.00 & 50.00 & 55.00 & - & - & - & - & - \\
Paddy straw & 48.00 & 11.00 & 27.50 & 22.00 & 13.00 & 33.00 & - & - \\
Cashew litter & - & - & - & 38.00 & 24.00 & 39.00 & 22.50 & 2.60 & 67.00 \\
Mango litter & - & - & - & 48.00 & 30.00 & 50.00 & 30.70 & 28.60 & 6.30 \\
Guava litter & - & - & - & 44.00 & 14.00 & 83.00 & 25.00 & 23.00 & - \\
Eucalyptus litter & - & - & - & 32.00 & 10.00 & 61.00 & 31.00 & 24.40 & 11.60 \\
\hline
\end{tabular}

Note: Col: 1-3 data for first month

(1) Percent loss of litter per month due to microbial degradation and feeding by earthworms.

(2) Percent microbial degradation per month.

(3) Rate of litter consumption (mg) for hundred earthworms per day.

Col: 4-6 data for second month

(4) Percent loss of litter per month due to microbial degradation and feeding by earthworms.

(5) Percent microbial degradation per month.

(6) Rate of litter consumption (mg) for hundred earthworms per day.

Col: 7-9 data for third month

(7) Percent loss of litter per month due to microbial degradation and feeding by earthworms.

(8) Percent microbial degradation per month.

(9) Rate of litter consumption (mg) for hundred earthworms per day.

The table also shows the acceleration of litter breakdown in presence of earthworms.

affecting density and surface cast production. The casts of the earthworm, Pontoscolex corethrurus, and the surrounding soil in an undisturbed forest floor in Sirumalai Hills, Tamil Nadu (South India) showed that the percentage of moisture content, organic carbon, and total nitrogen in the worm casts were higher and significantly differed from the values obtained in the surrounding soil [20].

According to the recent report by Julka et al. [21], in India, there are 590 species of earthworms with different ecological preferences, but the functional role of the majority of the species and their influence on the habitat are lacking. Recently Karmegam and Daniel [11] reported the correlation of soil and environmental parameters on the abundance of ten different earthworm species belonging to four families, namely, Megascolecidae (Lampito mauritii, L. kumiliensis, and Megascolex insignis), Octochaetidae (Dichogaster bolaui, D. saliens, and Octochaetona thurstoni), Moniligastridae (Drawida chlorina, D. paradoxa, and D. pellucida pallida), and Glossoscolecidae (Pontoscolex corethrurus) in the study that was carried out at different locations in Dindigul District (South India). The fluctuations in populations of earthworms were observed during the monthly collections in course of three years in all the selected sites. In the survey carried out from 1997 to 1999, the predominant species that were recorded as maximum number of earthworms $/ \mathrm{m}^{2}$ in sites 1-10 were D. pellucida pallida (Jan. 1998-70.44), D. pellucida pallida (Dec. 1999-32.30), L. mauritii (Feb. 1998-55.22), D. pellucida pallida (Dec. 1999-25.54), L. mauritii (Dec. 1997-66.78), L. mauritii (Nov. 1997-43.40), L. mauritii (Jan. 1999-44.60), P. corethrurus (Nov. 1997-58.34), 
P. corethrurus (Dec. 1999-64.30), and P. corethrurus (Dec. 1998-107.60) [22].

The biomass dynamics also showed wide fluctuation among the species in relation to the months of collection from different collection sites. The highest worm biomass was recorded during December to February and certain species were totally absent during certain periods of the survey. The total biomass of different species recorded in the monthly observation over a period of three years (1997 to 1999) varied in various study sites. The highest biomass of the respective earthworm species as well as the month and year of its occurrence in the study sites 1 to 10 as recorded includes D. pellucida pallida $\left(30.63 \mathrm{~g} / \mathrm{m}^{2}\right.$ during Feb. 1998), D. pellucida pallida $\left(22.88 \mathrm{~g} / \mathrm{m}^{2}\right.$ during Jan. 1998), D. pellucida pallida $\left(29.27 \mathrm{~g} / \mathrm{m}^{2}\right.$ during Dec. 1999), D. pellucida pallida (20.20 g/ $\mathrm{m}^{2}$ during Dec. 1999), D. pellucida pallida (44.65 g/ $\mathrm{m}^{2}$ during Dec. 1999), D. pellucida pallida (22.38 g/ $\mathrm{m}^{2}$ during Dec. 1999), D. pellucida pallida $\left(29.66 \mathrm{~g} / \mathrm{m}^{2}\right.$ during Jan. 1998), P. corethrurus $\left(15.20 \mathrm{~g} / \mathrm{m}^{2}\right.$ during Dec. 1998), D. bolaui $\left(19.79 \mathrm{~g} / \mathrm{m}^{2}\right.$ during Jan. 1999), and P. corethrurus (26.34 g/ $\mathrm{m}^{2}$ during Dec. 1998), respectively [22]. Among the earthworm species studied, L. kumiliensis has been reported for the first time in Sirumalai Hills of Tamil Nadu, India [23]. This is the only study to highlight the cyclic fluctuations in the earthworm populations for a continuous period of three years and variations in the species structure at different time intervals. Still the information on the physicochemical changes in the soil with respect to species composition at given time is not clear. A composite study on microbial association with the predominant earthworm species at a given time may provide necessary information on its ecological role.

\section{Factors Influencing the Abundance of Earthworm Populations}

The percentage abundance of different species of earthworms in the 10 collection sites during the survey period (19971999 ) is shown in Figures 1 and 2. In most of the study sites, that is, $1-7$, L. mauritii was the dominant species and it showed its presence during the premonsoon, monsoon, and postmonsoon months. $P$. corethrurus showed its abundance in the sites 8-10. Various parameters, that is, $\mathrm{pH}$, electrical conductivity (EC), organic carbon (OC), nitrogen $(\mathrm{N})$, atmospheric temperature (AT), soil temperature (ST), soil moisture (SM), humidity (HUM), and rainfall (RF) observed during the survey period (1997-1999) are given in Table 5 and in Figure 3. All the parameters showed fluctuations in all the ten study sites. Here, for the convenience of statistical analysis the parameters were categorized into two major groups: (a) physicochemical parameters which included $\mathrm{pH}$, EC, OC, and N; and (b) climatic parameters which included ST, SM, HUM, and RF.

In Tamil Nadu, India, very limited information is available on the distribution pattern of earthworms. The data on earthworm distribution is available for the stations like Palni Hills [24], Madras [25], and Sirumalai Hills [11, 23, 26, 27]. Dindigul, a District in Tamil Nadu, was considered as
Table 4: Artificial diet (1:8 by weight) of agar and different leaf litter powder on feeding of earthworm Lampito mauritii in relation to $\mathrm{C} / \mathrm{N}$ of diets [5].

\begin{tabular}{lcc}
\hline $\begin{array}{l}\text { Litter powder in } \\
\text { agar }\end{array}$ & $\begin{array}{c}\text { Daily food } \\
\text { intake } \\
\text { mg/day/adult }\end{array}$ & $\begin{array}{c}\mathrm{C} / \mathrm{N} \text { of } \\
\text { the feed }\end{array}$ \\
\hline Paddy straw & $8.05 \pm 0.28$ & 37 \\
Millet straw & $7.07 \pm 1.23$ & 45 \\
Mango litter & $8.67 \pm 1.27$ & 19 \\
Guava litter & $3.25 \pm 0.79$ & 45 \\
Cashew litter & $4.44 \pm 1.10$ & 30 \\
Eucalyptus litter & $1.62 \pm 0.59$ & 42 \\
Agar only (control) & $2.53 \pm 1.23$ & 38 \\
\hline
\end{tabular}

Number of observations $=3$; Palatability depends on texture as well as chemical nature of the feed.

study site for its variety of habitats to assess the earthworm species diversity, density, and biomass. The population and biomass dynamics of different earthworm species and their percentage abundance in relation to physicochemical characteristics of the soil and the climatic factors were recorded in selected sites. The correlation of earthworm population to physicochemical characteristics of the soil and the climatic parameters was carried out to find out the possibility of arriving at a suitable endemic earthworm species for vermicomposting operations in this part of the country. Since the populations of earthworms are extremely variable in size ranging from only a few individuals (sometimes totally absent) to more than $1000 / \mathrm{m}^{2}$, the assessment of the size distribution and structure of earthworm population is difficult. The seasonal change, demography, and vertical distribution of the populations make it more complicated, and hence, it is absolutely essential to follow a uniform method of determining the number of earthworms in small sample areas as it has been done in this study. The regular monthly survey carried out for three years (1997 to 1999) showed the presence of ten species of earthworms, with four species restricted only to the hilly region and six species to the plain, including the foothills (Table 6). This observation indicates that species such as L. kumiliensis, D. bolaui, $D$. saliens, and $P$. corethrurus are specific only to the hilly region and they are not found in the foothills. Though L. kumiliensis and $L$. mauritii both belong to the same genus, Lampito, $L$. kumiliensis was found only in the hilly region and $L$. mauritii in the plains. This observation indicates that the distribution of different earthworm species is limited even though they are closely related. Such niche differences for closely related species have been reported by earlier workers in the field $[28,29]$.

The results of the percentage abundance of different species of earthworms showed that $L$. mauritii and $P$. corethrurus were the most abundant in the study sites 1 to 7 and 8 to 10 , respectively. Formation of aggregation of species has been observed in sites 1 to 7; that is, wherever L. mauritii was found, it was in association with $D$. chlorina and D. pellucida pallida. This sort of association of earthworm species sharing the same habitat is not 


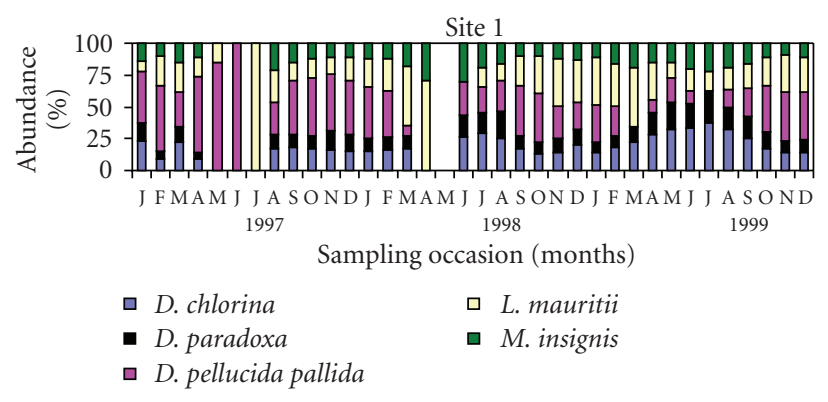

(a)

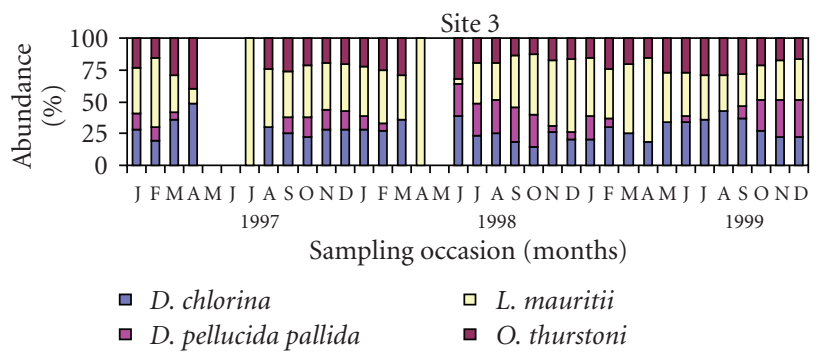

(c)

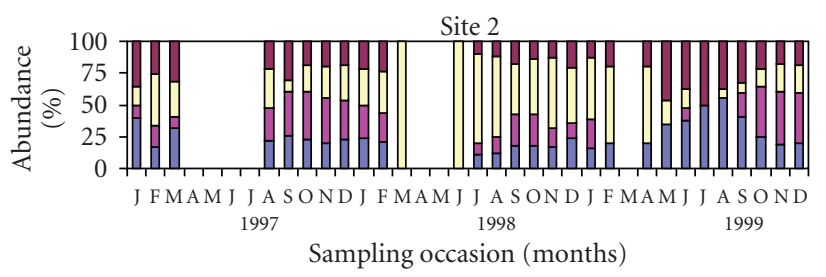

$\begin{array}{ll}\square \text { D. chlorina } & \square \text { L. mauritii } \\ \square \text { D. pellucida pallida } & \square \text { O. thurstoni }\end{array}$

(b)

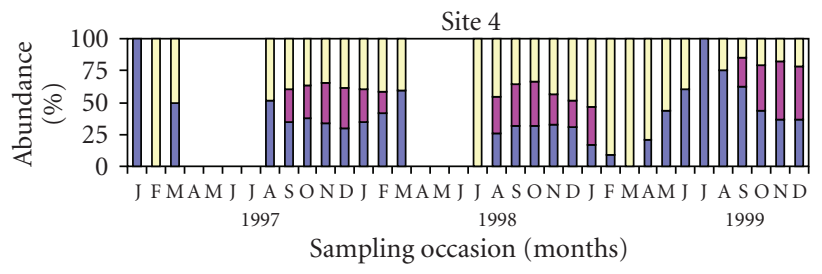

口 D. chlorina

- D. pellucida pallida

口 L. mauritii

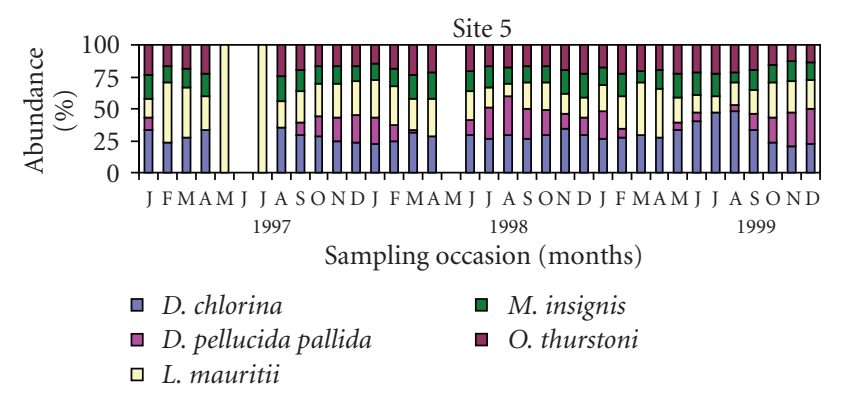

(e)

Figure 1: Percentage abundance of earthworm population in study sites 1 to 5 (1997-1999).

uncommon $[1,30]$. L. mauritii is the dominant species found almost all over India along with other earthworm species such as Drawida modesta, Octochaetona pattoni, O. thurstoni, Ramiella pachpaharensis, Polypheretima elongata, and Pontoscolex corethrurus [8,31], but Bano and Kale [32] reported that $L$. mauritii was not found in some forest areas and coastal Karnataka. The population densities of earthworms observed in the 10 collection sites ranged from 0 to $228 / \mathrm{m}^{2}$. Other authors observed population densities (earthworm no. $/ \mathrm{m}^{2}$ ) of 53.5 in plain grass land, 73 in deciduous forest, 543 in the fallow phases of shifting agriculture, and 58.2 in the maize crop land [33-36]. In rubber plantations of Tripura (India) about 20 species of earthworms, namely, Eutyphoeus gigas, E. gammiei, E. comillahnus, E. assamensis, E. festivas, Eutyphoeus sp., Dichogaster bolaui, D. affinis, Lennogaster chittagongensis, Octochaetona beatrix, Metaphire houlleti, Perionyx sp., Kanchuria sumerianus, Kanchuria sp.1, Kanchuria sp.2, Drawida nepalensis, Drawida sp.1, Drawida sp.2, Pontoscolex corethrurus, and Gordiodrilus elegans were distributed and it was observed that the largely dominating species were endogeics [37].
Evans and Guild [38] have shown that nitrogen rich diets help in rapid growth of earthworms and facilitate more cocoon production than those with little nitrogen available. Due to the influence of nitrogen content of the soil, the percentage contribution of nitrogen to earthworm population might have shown a very high degree of dependence in the present study. Some of the reports from the country well support qualitative dependence of earthworm population on soil nitrogen content $[26,27,39,40]$.

Soil moisture plays a major role in the distribution and occurrence of various earthworm species. The same has been observed by other workers in their studies [25, 28, 29, 41, 42]. The abundance and species diversity are dependent on climatic conditions, especially the occurrence of dry and/or cold periods, and regional variation in vegetation, soil texture, and nutrient content. The climatic parameters, that is, soil temperature, soil moisture, humidity, and rainfall show seasonal fluctuations (Table 6 and Figure 3). The highest rainfall was recorded during October-November and the earthworm population was also the highest at this period. The soil moisture content corresponded with earthworm 


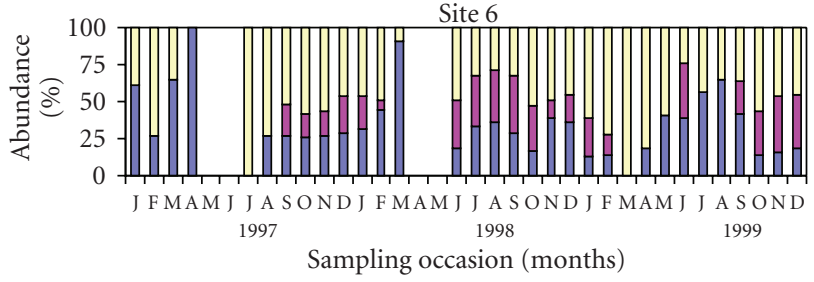

- D. chlorina

- D. pellucida pallida

L. mauritii

(a)

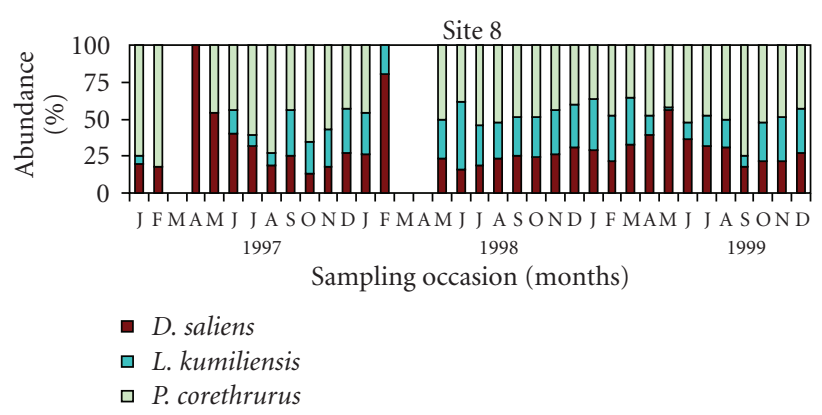

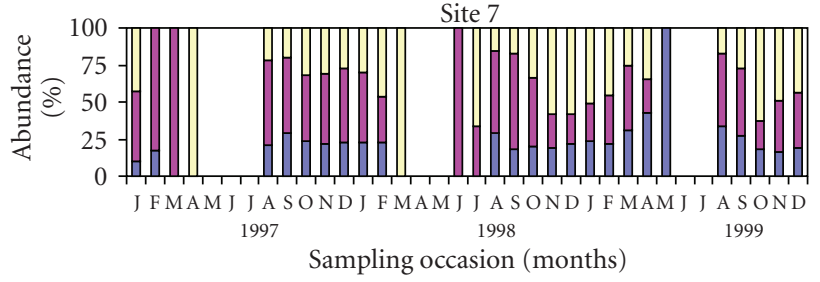

- D. chlorina

- D. pellucida pallida

口 L. mauritii

(b)

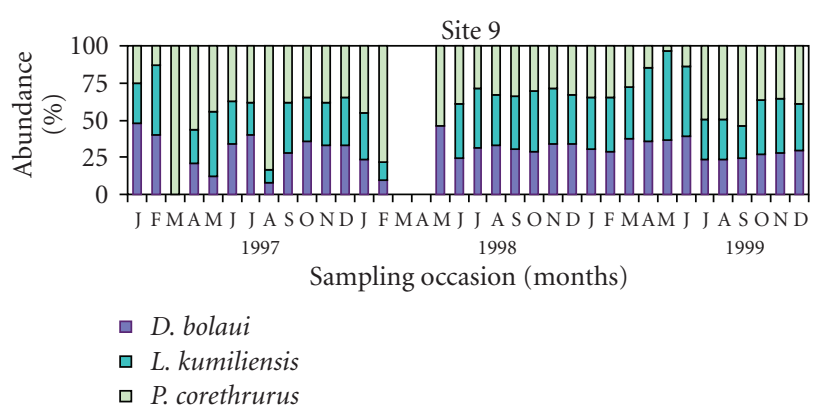

(d)

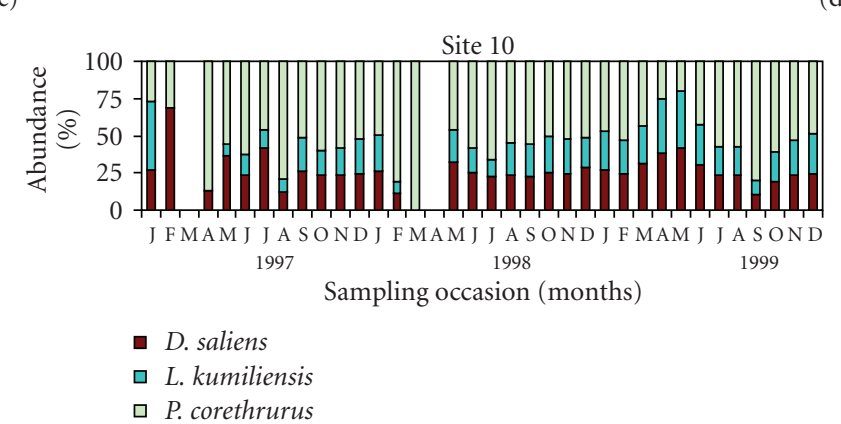

(e)

Figure 2: Percentage abundance of earthworm population in study sites 6 to 10 (1997-1999).

population. Total annual rainfall of 1130,1284 , and $959 \mathrm{~mm}$ was recorded during 1997, 1998, and 1999 in the plains and foothills of Sirumalai (study sites 1-7). The highest rainfall of 304 and $357 \mathrm{~mm}$ was received during October and November 1997 in the above study sites. The highest rainfall months in Sirumalai Hills (study sites 8-10) were October to December. The soil moisture content directly matched with the rainfall. The soil moisture content ranged from 2.0 to 30.4 percent in the study sites 7-10 during the three years of the study. The humidity also showed fluctuations in both the plains and hilly region of the study area. Soil moisture can explain the increase in earthworm population, since soils are moist under a mulch cover because of the restricted evaporation. There are many indications, to show that the population of endogeic earthworms is controlled mainly by soil moisture [42].

The influence of climatic factors on the populations of earthworm is not uncommon. The populations of Millsonia anomala are dependent on climatic conditions as well as vegetational patterns. Earthworm activity and populations are determined essentially by the moisture content of the soil [43]. The temperature and moisture are usually inversely related and higher surface temperature and dry soils are limiting factors to earthworms than low and water logged soils [44]. The soil temperature plays an important role in the maintenance of earthworm population in an ecosystem and available information also indicates the negative correlation of soil temperature to earthworm population $[11,25,40,45]$. In rubber plantations of Tripura (India), the earthworms experienced $25.9^{\circ} \mathrm{C}, 24.8 \%, 4.85$, and $1.8 \%$ mean soil temperature, moisture, $\mathrm{pH}$, and organic matter, respectively [37]. Temperature largely affects activity of earthworms in temperate regions. Tropical species can withstand higher temperatures. L. mauritii is available throughout the year where the annual temperature is $30 \pm 2^{\circ} \mathrm{C}$. Population of $O$. serrata was active between 27 and $28^{\circ} \mathrm{C}$. In tropical regions the temperature fluctuations are minimal when compared to temperate regions.

Moisture is another limiting factor for earthworm distribution as water constitutes a major portion of the body 
TABle 5: Physicochemical and climatic characteristics (average) of the study sites 1 to 10 (1997-1999) (refer to Table 6 for study site description) [22].

\begin{tabular}{|c|c|c|c|c|c|c|c|c|c|c|}
\hline \multirow{2}{*}{ Parameter observed* } & \multicolumn{10}{|c|}{ Study sites } \\
\hline & 1 & 2 & 3 & 4 & 5 & 6 & 7 & 8 & 9 & 10 \\
\hline \multicolumn{11}{|l|}{1997} \\
\hline $\mathrm{pH}$ & 7.78 & 7.63 & 7.13 & 6.86 & 7.59 & 7.67 & 6.78 & 7.04 & 7.50 & 6.55 \\
\hline $\mathrm{EC}(\mathrm{dS} / \mathrm{m})$ & 0.34 & 0.20 & 0.38 & 0.11 & 0.21 & 0.18 & 0.32 & 0.14 & 0.27 & 0.39 \\
\hline $\mathrm{OC}(\%)$ & 1.42 & 2.29 & 4.44 & 2.75 & 1.47 & 2.94 & 3.42 & 3.05 & 4.20 & 7.99 \\
\hline $\mathrm{TN}(\%)$ & 0.41 & 0.35 & 0.23 & 0.23 & 0.25 & 0.40 & 0.42 & 0.31 & 0.22 & 0.40 \\
\hline $\mathrm{ST}\left({ }^{\circ} \mathrm{C}\right)$ & 28.90 & 29.83 & 27.84 & 29.29 & 30.31 & 29.27 & 29.83 & 23.47 & 22.49 & 21.30 \\
\hline $\mathrm{SM}(\%)$ & 8.10 & 6.34 & 10.34 & 7.22 & 7.16 & 8.30 & 10.25 & 15.75 & 15.46 & 14.99 \\
\hline \multicolumn{11}{|l|}{1998} \\
\hline $\mathrm{pH}$ & 7.95 & 7.51 & 7.25 & 6.66 & 7.51 & 7.62 & 6.45 & 7.15 & 7.34 & 6.44 \\
\hline $\mathrm{EC}(\mathrm{dS} / \mathrm{m})$ & 0.36 & 0.22 & 0.38 & 0.13 & 0.25 & 0.16 & 0.33 & 0.18 & 0.31 & 0.39 \\
\hline OC (\%) & 1.74 & 2.19 & 4.24 & 2.79 & 1.43 & 2.35 & 4.25 & 3.19 & 4.22 & 8.48 \\
\hline TN (\%) & 0.44 & 0.34 & 0.24 & 0.27 & 0.27 & 0.41 & 0.41 & 0.27 & 0.27 & 0.38 \\
\hline ST $\left({ }^{\circ} \mathrm{C}\right)$ & 29.23 & 30.18 & 28.27 & 30.63 & 29.92 & 29.30 & 30.18 & 24.14 & 22.68 & 21.30 \\
\hline SM (\%) & 12.14 & 9.93 & 15.18 & 9.73 & 12.83 & 12.03 & 14.35 & 16.00 & 17.09 & 16.29 \\
\hline \multicolumn{11}{|l|}{1999} \\
\hline $\mathrm{pH}$ & 7.85 & 7.49 & 7.37 & 6.85 & 7.38 & 7.59 & 6.47 & 6.98 & 7.45 & 6.64 \\
\hline $\mathrm{EC}(\mathrm{dS} / \mathrm{m})$ & 0.35 & 0.23 & 0.34 & 0.14 & 0.24 & 0.17 & 0.35 & 0.16 & 0.26 & 0.39 \\
\hline OC (\%) & 1.40 & 2.45 & 4.34 & 2.90 & 1.36 & 3.02 & 4.05 & 3.45 & 4.37 & 9.99 \\
\hline $\mathrm{TN}(\%)$ & 0.46 & 0.37 & 0.27 & 0.26 & 0.26 & 0.43 & 0.41 & 0.31 & 0.28 & 0.39 \\
\hline ST $\left({ }^{\circ} \mathrm{C}\right)$ & 27.42 & 28.55 & 26.49 & 29.66 & 30.42 & 27.46 & 28.55 & 25.21 & 23.51 & 22.80 \\
\hline SM (\%) & 9.50 & 7.27 & 11.70 & 8.50 & 9.27 & 9.37 & 10.34 & 12.56 & 14.37 & 13.86 \\
\hline
\end{tabular}

${ }^{*}$ EC: Electrical conductivity; OC: Organic carbon; TN: total nitrogen; ST: Soil temperature; SM: Soil moisture.

weight of an earthworm. Soil moisture and population estimates are positively correlated [35]. Water constitutes 75-90 percent of the body weight of earthworms. So the prevention of water loss is a major factor for their survival. They apparently lack a mechanism to maintain constant internal water content, so that their water content is influenced greatly by the water potential of the soil [46], which directly depends on the adequate availability of soil moisture.

The seasonal dynamics in an annual cycle shows that earthworm numbers and biomass were high in the rainy season with a gradual decline in number in the winter season. Earthworms were completely absent during the second half of January and February, when soil temperature was very low $\left(4.9-6.2^{\circ} \mathrm{C}\right)$. Dash and Patra [7] and Kale and Krishnamoorthy $[8,47]$ have recorded maximum number of earthworms and biomass in the rainy and late rainy period. The relationship between earthworm activity and rainfall was observed by Fragoso and Lavelle [48] and Joshi and Aga [49]. The moisture requirements for different species of earthworms from different regions can be quite different [42]. The dependence of earthworm population on soil moisture is seen in the studies carried out for three years as of the highest degree when compared with other climatic parameters. This is because of certain physiological activities of earthworms such as cutaneous respiration and excretion of nitrogenous ammonia and urea, which need a moist environment, which, in turn, is essential for the maintenance of their life process.

Systematic correlation analysis results indicate that only about 80 percent of the population dependence can be explained by these physicochemical and climatic parameters and it is presumed that the remaining may depend on other environmental factors. The correlation analysis technique may be used to quantify and rationalize the effects of physicochemical parameters on the earthworm population. However, no single factor is likely to be solely responsible for the horizontal distribution of earthworms, but rather the interaction of several of the factors provides suitable soil conditions for the existence of earthworm populations [11].

\section{Earthworm Casts: Abundance, Structure, and Properties}

Earthworms' release "cast" at the opening of their burrows. Epigeic earthworms release the castings exclusively on soil surface. Their castings may be granular or spindle like masses that may be 2 to $3 \mathrm{~cm}$ high heaps as in Eudrilus eugeniae or Perionyx excavatus. There is no definite shape to the excreted matter to identify as castings of Eisenia fetida. Eisenia fetida releases fine, powdery, dark brown material as surface cast. Soil living endogeic earthworms that feed on different quantities of organic matter along with soil particles 
TABle 6: Population density of earthworms in different habitats in Dindigul District, Tamil Nadu studied during 1997-1999 [22].

\begin{tabular}{|c|c|c|c|}
\hline Study site & Description & Earthworm species & Avg. population density (no. $\left./ \mathrm{m}^{2}\right)$ \\
\hline \multirow{5}{*}{ (1) } & \multirow{5}{*}{ Cultivated land } & Lampito mauritii (Kinb.). & 12.52 \\
\hline & & Megascolex insignis Mich. & 7.82 \\
\hline & & Drawida chlorina (Bourne). & 8.88 \\
\hline & & Drawida paradoxa Rao. & 5.10 \\
\hline & & Drawida pellucida var. pallida Mich. & 18.60 \\
\hline \multirow{4}{*}{ (2) } & \multirow{4}{*}{ Unirrigated crop land } & Lampito mauritii (Kinb.). & 14.18 \\
\hline & & Octochaetona thurstoni Mich. & 5.46 \\
\hline & & Drawida chlorina (Bourne). & 5.04 \\
\hline & & Drawida pellucida var. pallida Mich. & 11.10 \\
\hline \multirow{4}{*}{ (3) } & \multirow{4}{*}{ Uncultivated shaded fallow land } & Lampito mauritii (Kinb.). & 17.88 \\
\hline & & Drawida pellucida var. pallida Mich. & 13.27 \\
\hline & & Octochaetona thurstoni Mich. & 10.92 \\
\hline & & Drawida chlorina (Bourne). & 10.70 \\
\hline \multirow{3}{*}{ (4) } & \multirow{3}{*}{ Uncultivated fallow land } & Lampito mauritii (Kinb.). & 10.30 \\
\hline & & Drawida chlorina (Bourne). & 4.73 \\
\hline & & Drawida pellucida var. pallida Mich. & 6.46 \\
\hline \multirow{5}{*}{ (5) } & \multirow{5}{*}{ Garden } & Lampito mauritii (Kinb.). & 15.50 \\
\hline & & Megascolex insignis Mich. & 10.96 \\
\hline & & Octochaetona thurstoni Mich. & 13.04 \\
\hline & & Drawida chlorina (Bourne). & 17.26 \\
\hline & & Drawida pellucida var. pallida Mich. & 11.27 \\
\hline \multirow{3}{*}{ (6) } & \multirow{3}{*}{ Orchard } & Lampito mauritii (Kinb.). & 8.92 \\
\hline & & Drawida chlorina (Bourne). & 6.32 \\
\hline & & Drawida pellucida var. pallida Mich. & 4.75 \\
\hline \multirow{3}{*}{ (7) } & \multirow{3}{*}{ Foothills (Alt. < 450 m.) } & Lampito mauritii (Kinb.). & 5.63 \\
\hline & & Drawida chlorina (Bourne). & 6.22 \\
\hline & & Drawida pellucida var. pallida Mich. & 22.68 \\
\hline \multirow{3}{*}{$(8)$} & \multirow{3}{*}{ Grass land (Alt. 1,000 m.) } & Lampito kumiliensis (Kinb.). & 18.21 \\
\hline & & Dichogaster saliens (Bedd.). & 5.31 \\
\hline & & Pontoscolex corethrurus (Muller). & 10.30 \\
\hline \multirow{3}{*}{ (9) } & \multirow{3}{*}{ Semi-evergreen forest (Alt. 1,100 m.) } & Lampito kumiliensis (Kinb.). & 29.52 \\
\hline & & Pontoscolex corethrurus (Muller). & 10.49 \\
\hline & & Dichogaster bolaui (Mich.). & 9.39 \\
\hline \multirow{3}{*}{ (10) } & \multirow{3}{*}{ Sacred grove land (Alt. 1,300 m.) } & Lampito kumiliensis (Kinb.). & 19.42 \\
\hline & & Dichogaster saliens (Bedd.). & 9.37 \\
\hline & & Pontoscolex corethrurus (Muller). & 19.16 \\
\hline
\end{tabular}

use part of their castings to strengthen their burrow walls and the rest is released as castings. Castings of these earthworms may be ovoid or irregularly shaped minute mounds. Though the nature of cast released is characteristic of a species, this cannot be criterion for their identification [50]. If pellet-like castings are released by Pheretima posthuma, Perionyx millardi releases thread-like castings. Thick and long winding columns of hollow mound of $5 \mathrm{~cm}$ long and $2.5 \mathrm{~cm}$ wide casts are characteristic of Hoplochaetella khandalaensis. The biggest cast of Notoscolex birmanicus weighing $1.6 \mathrm{~kg}$ after drying for four months is reported from Burma [50]. Polypheretima elongata and Pontoscolex corethrurus excrete the ingested soil as sticky, thick lumps on soil surface.
Amount of cast produced can serve as an index for assessing earthworm activity. Immediately after rains, release of surface casts will be at a maximum level. At this point of time, majority of earthworms are found at 0 to $10 \mathrm{~cm}$ depth and very few of them are found at 20 to $30 \mathrm{~cm}$ depth (Kale and Dinesh, 2005, unpublished). Surface cast production has been quantified in different agro-ecosystems to relate it to their abundance [51-53]. Influence of seasonal variation and land use pattern was observed with respect to cast production in shifting agriculture [34]. Norgrove and Hauser [54] have recorded around 30 to $35 \mathrm{t} / \mathrm{ha}$ of cast production in tropical silvicultural system. Reddy [55] has reported annual production of 23.4 to 140.9 tonnes by Pheretima alexandri. According to Lavelle [56], cast production is rhythmic and 


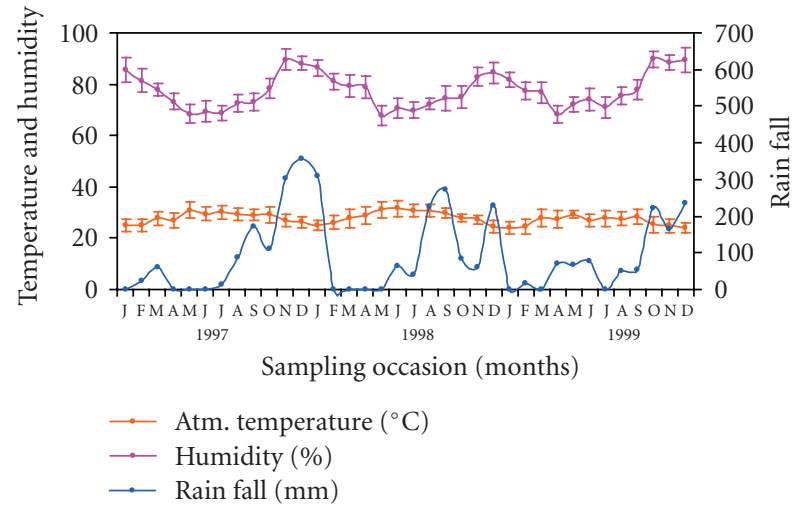

(a)

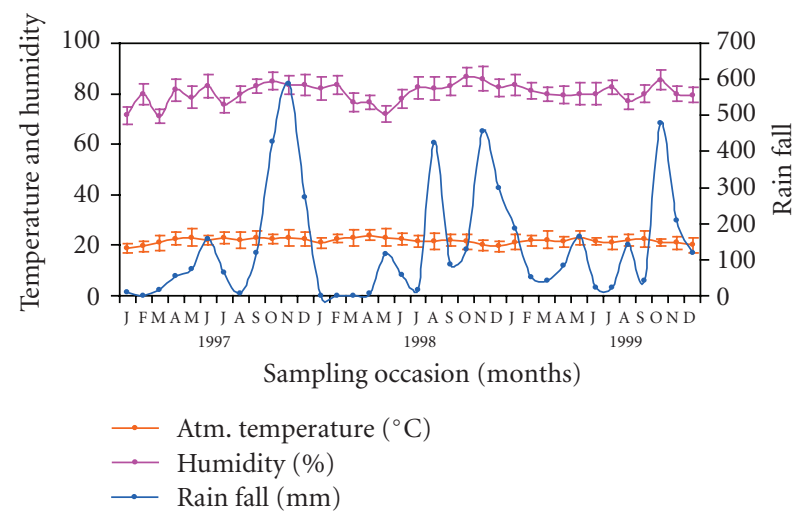

(b)

FIGURE 3: Atmospheric temperature (mean \pm SD), Humidity (mean \pm SD), and average rainfall of the study sites 1-7 (a) and 8-10 (b).

TABLE 7: Earthworm cast production during early postmonsoon period (Nov. 2004) at different agro-ecosystems in Kuti village of Somavarpatna Taluk of Karnataka State (Kale and Dinesh 2004, unpublished).

\begin{tabular}{lc}
\hline Land uses & Castings (Kg/Sq. M) \\
\hline Natural forest & $11.20 \pm 0.46$ \\
Coffee plantation & $17.2 \pm 0.53$ \\
Cardamom plantation & $16.80 \pm 1.00$ \\
Paddy fields (after & $13.60 \pm 1.00$ \\
harvest) & $2.40^{*}$ \\
Acacia plantation & $0.8^{*}$ \\
Grassland & \\
\hline
\end{tabular}

${ }^{*}$ Due to dryness prevailing at the collection spots castings could be collected only from single spots out of 6 and 8 monolith points.

it will be at maximum at early morning hours. In general cast production in tropical countries is restricted to wet seasons. Table 7 provides the information on earthworm cast production in different agro-ecosystems during onset of postmonsoon season in the state of Karnataka, India.

The physicochemical properties of casts depend on the habitat soil and species of earthworm [57]. Their aggregate stability depends on the available organic matter [58]. The stability of casts and stability of fragmented casts on disintegration are the important factors to determine the soil structure [1]. Aggregate stability may result from addition of mucus secretion from earthworm gut and of associated microorganisms in the gut. It may also be due to macerated organic particles in the castings that encourage microbial activity after its release from the gut [59]. According to Parle [60], stability of casts is due to fungal succession that takes place in the cast. Habibulla and Ismail [61] are of the opinion that soil texture, particle size, and porosity play an important role in burrowing and surface cast production. As casting activity is restricted to wet seasons, not much of attention is paid to assess the quantum of cast produced and its influence on soil physical, chemical, and biological properties as is available from other parts of the world. It is essential to know the physicochemical and biological variations that may be seen in cast produced by the same species of earthworm inhabiting places that differ in physiographic and edaphic conditions. This will provide the information on interrelationship of earthworms, original soil characters, and nature of available organic material that influence the change in soil characters through deposition of earthworm cast. The fertile lands turning unproductive in Himachal Pradesh, India, due to sticky castings of earthworms that turned the soil into cement-like clods had been reported [62]. Puttarudraiah and Sastry [63] had observed stunting of growth in root crops like carrot, radish, and beetroots due to castings of Pontoscolex corethrurus in pot culture studies.

Castings of earthworms are the "store house" of nutrients for plants. The increased earthworm activity with increase in availability of carbon and in turn a raise in available nitrogen and phosphorus in their castings was also reported [6]. Earthworm activity has shown to improve the soil aggregates and soil minerals that are more available to plants than from soil $[54,64]$. It is clear from various studies that earthworm casts may have more important role in plant nutrition and nutrient cycling than it was assumed previously $[65,66]$. In India, very early reports are available on such observations on the chemical properties of earthworm castings that can play a positive role in plant growth [57, 67, 68]. The chemical composition of casts, which is widely studied, is of holonephric lumbricid earthworms. In subtropical country like India where majority of earthworms are meronephric, their castings may show higher level of available plant nutrients than surrounding soil. Dash and Patra [7, 53] had reported higher levels of nitrogen in casts of Lampito mauritii than in surrounding soil. Ganeshmurthy et al. [69] have found higher rate of mobilization of micronutrients in earthworm castings. It requires further studies on meronephric Megascolecid earthworms and their castings on available and exchangeable forms of nutrients to assess their contribution to soil fertility. Kale and Krishnamoorthy [70] had shown increased levels of soluble calcium and carbonates in castings of Pontoscolex corethrurus. Soluble carbonates contribute to exchangeable base contents of castings (Table 8). The physicochemical properties like $\mathrm{pH}, \mathrm{EC}$, organic $\mathrm{C}$, total $\mathrm{N}$, available $\mathrm{P}, \mathrm{K}$, $\mathrm{Na}, \mathrm{Ca}$, and $\mathrm{Mg}$ of casts did not differ in zero tillage land treated with mulch of residues of annuals or perennials [19]. The population dynamics of a peregrine earthworm, 
TABle 8: Calcium and carbonates in castings of Pontoscolex corethrurus compared with that of habitat soil [70].

\begin{tabular}{lcc}
\hline \multirow{2}{*}{ Constituents } & \multicolumn{2}{c}{$\mu \mathrm{g} / \mathrm{g}$ dry weight } \\
& Soil & Castings \\
\hline Ionic Calcium & $12.24 \pm 0.41$ & $145.50 \pm 9.81$ \\
Exchangeable Calcium & $12.83 \pm 0.37$ & $95.23 \pm 7.28$ \\
Insoluble Calcium & $179.62 \pm 0.02$ & $32.09 \pm 0.93$ \\
Ionic/Insoluble Carbonate & $0.15 \pm 0.01$ & $6.98 \pm 2.22$ \\
\hline
\end{tabular}

Pontoscolex corethrurus, in undisturbed soil of Sirumalai Hills clearly showed that the parameters like rainfall, humidity, soil moisture, and organic carbon influence the population positively $[26,27]$. It has also been reported that in rubber plantations of Tripura, a part of north-east India, Pontoscolex corethrurus was the dominant species, representing $61.5 \%$ biomass and $72 \%$ density of the total earthworm population where it might be linked to individual tree species effect (Hevea brasiliensis) that favoured P. corethrurus over other species [37].

\section{Earthworms and Microflora}

Earthworm activity is closely associated with microbial activity. Lavelle [2] is of the opinion that there may exist competition between microorganisms and earthworms for easily digestible and energy rich substrates. Such competition may depend on availability of nutrients in the medium. Contrary to this, earthworms may derive benefit from microorganisms when they have to survive on materials rich in cellulose or hemi cellulose. So there exists mutualistic relation between earthworms and microorganisms. Tiunov and Scheu [6] have shown that earthworms deprive easily available carbon to microorganisms and availability of carbon increases effective mobilization of $\mathrm{N}$ and $\mathrm{P}$ by earthworms. The complex interrelationship of earthworms and microorganisms is at the level of their digestive tract, castings, and burrow walls [71]. This establishes the probable mutualism that exists between earthworms and microorganisms. Joshi and Kelkar [68] demonstrated higher microbial activity in earthworm castings and their role in mineralization of nitrogen. They incubated known weights of groundnut cake in a pot containing earthworm castings and other containing soil from the same place. The release of $\mathrm{N}$ from groundnut cake was at a higher level in pot containing castings than from one having soil as the medium.

Bhat et al. [72] were the pioneer contributors to report on role of microorganisms in the gut of earthworms. Khambata and Bhat [73] had made a detailed investigation on intestinal microflora of Pheretima sp. They had isolated Pseudomonas, Corenyform bacteria, Nocardia, Streptomyces, and Bacillus from the intestinal tract. There is no report of nitrosofying and nitrifying bacteria in their observations in the gut of earthworms. Dash et al. [74] have reported about isolation of 16 fungi from different parts of the gut out of 19 found in their habitat. In the fresh castings of the same earthworms there were only seven fungi with antibiotic properties or with
TABLE 9: Microbial population in neem cake enriched vermicompost $[80]$.

\begin{tabular}{lcc}
\hline $\begin{array}{l}\text { Microbial population } \\
\text { no./g vermicompost }\end{array}$ & $\begin{array}{c}\text { Vermicompost } \\
\text { with } 2 \% \text { neem } \\
\text { cake }\end{array}$ & $\begin{array}{c}\text { Vermicompost } \\
\text { without neem } \\
\text { cake }\end{array}$ \\
\hline Fungi no. $\times 10^{4}$ & 22.3 & 5.2 \\
Bacteria no. $\times 10^{6}$ & 15.0 & 7.8 \\
Nitrogen fixers no. $\times 10^{5}$ & 54.1 & 6.6 \\
\hline
\end{tabular}

thick spore coats. This suggests the selective fungal feeding by earthworms.

Drillosphere is the focus for understanding earthworm microbe interrelationship. This association is also associated with land use and metabolizable carbon present in the soil. Metabolizable carbon has positive effect on both microorganisms and earthworms [75]. Microbial activity will be at a higher level in the drillosphere than in surrounding soil and other edaphic factors determine the microbial diversity in drillosphere [76]. According to Kretzschmar [77], interaction of soil fauna and microflora determines soil dynamics. The contribution of their activity for formation of humus is an index for soil fertility. Bhatnagar [78] had expressed that at 20 to $40 \mathrm{~cm}$ depth in drillosphere zone there were $40 \%$ aerobic $\mathrm{N}$-fixers, $13 \%$ anaerobic $\mathrm{N}$-fixers, and $16 \%$ of denitrifiers. $\mathrm{He}$ attributed low $\mathrm{C} / \mathrm{N}$ ratio in soils rich in earthworm population because of stimulation of $\mathrm{N}$-fixers in drillosphere. Drillosphere provides necessary substrate for growth and establishment of microorganisms.

Recent developments in the country as well as at the global level are the application of detritivorous epigeic earthworms for organic manure/vermicompost production from biodegradable organic materials recovered from agricultural lands, agro-based industries, and municipal solid waste. This field of study is closely associated with earthworm microbe interaction. The quality of the manure or vermicompost depends on microorganisms associated with the process of decomposition. Bhat [79] had reported that the diet formulation or the composition of organic matter used as feed influences the microflora associated with earthworm activity. Similar studies were made on enhanced $\mathrm{N}$-fixers activity on using $2 \%$ neem cake in the feed mix of earthworm Eudrilus engeniae [80] (Table 9).

During winter months in Himalayan region, fungal population was higher in vermicomposting system than in the native soil [81]. Maintenance of temperature in vermicomposting system at a favourable level for earthworm activity might have been the reason for establishment of fungal population. Press mud, a by-product of sugar industry, is often used as one of the substrates in vermicomposting. Subjecting of this material to earthworm activity along with other organic matter has resulted in changes in microbial populations [82]. Rajani et al. [83] have related the microbial density and enzyme activity as a measure to assess the effectiveness of process of vermicomposting. It is essential to make an in-depth study to understand the mutualistic association between microflora and earthworms in mechanism of decomposition of organic matter. 
An increase in actinomycetes population was observed in the gut region of earthworms. Some of the isolates from gut region of earthworms have expressed growth stimulatory effect when used in pot cultures of tomato and finger millet [84].

The colony forming units (CFUs) of bacteria and fungi in the casts of $P$. corethrurus significantly deviated from the CFU found in adjacent soil. The correlation between the physicochemical parameters and microbial populations of the casts of $P$. corethrurus showed that the establishment of microbial population requires optimum moisture, organic carbon, and nitrogen content [20]. The vermicasts of $P$. ceylanensis showed 14 different fungal species belonging to the genera, Aspergillus, Chaetomium, Cladosporium, Cunninghamella, Fusarium, Mucor, Penicillium, and Rhizopus. Total nitrogen, phosphorus, potassium, calcium, copper, iron, and zinc were higher in vermicasts than in control (substrate without earthworms) while organic carbon and $\mathrm{C} / \mathrm{N}$ ratio were lower in vermicasts. The total organic carbon was $42.3 \%$ in the control whereas it was $35.2 \%$ in the vermicasts of $P$. ceylanensis. The incubation of vermicasts (45 days) showed significant correlation with that of the increase in fungal population $(r=0.720 ; P<.05)$ and decrease in moisture content $(r=-0.984 ; P<.001)$, and the decrease in moisture content statistically had no effect on the total fungal population in the vermicasts of P. ceylanensis [85]. The total microbial population, namely, bacteria, fungi, and actinomycetes was found to be manyfold higher than in the initial vermibed substrate and in substrate without earthworms (control). The initial count of bacteria, fungi, and actinomycetes in the control was 123.42 CFU $\times 10^{7} \mathrm{~g}^{-1}, 159.64 \mathrm{CFU} \times 10^{3} \mathrm{~g}^{-1}$, and 86.90 CFU $\times$ $10^{4} \mathrm{~g}^{-1}$ whereas in castings (vermicompost) of $P$. ceylanensis the reported microbial populations were 268.62, 223.39, and 141.09 [86]. These observations clearly indicate the importance of microorganisms associated with earthworms in creating suitable environment for the standing crops as well as for vermicomposting of different organic wastes. It is still at the infancy to draw any inference regarding earthworm, microbe, and plant association.

Studies are also in progress to assess the inhibitory effects of the principles present in the body wall, gut extract, and of coelomic fluid on some selected plant and animal pathogens. The studies are at preliminary stages and it will require some more time to draw any conclusions based on the available data. Such interdisciplinary applications of earthworm research help to understand the functional complexity of these organisms other than their contribution to management of organic biodegradable residues as the major secondary detritivorous group.

\section{Earthworms as Bioindicators}

Earthworms can also serve as indicators of several changes/ factors associated with soil. Many studies clearly showed that the earthworms are best indicators of heavy metals, toxic pollutants, and direct and indirect anthropogenic changes in soil [87-89]. A study conducted in northern semiarid region of India showed the presence of earthworms to the maximum level wherever the farmers followed integrated farming (100\%) practice and this was followed by organically managed (70\%) and conventional (18.9\%) agro-ecosystems. The earthworm abundance was directly related to the management practices and the values of ecological indices like Shannon diversity $\left(\mathrm{H}^{\prime}\right)$, species dominance $(\mathrm{C})$, the species richness (S), and evenness (E). This clearly illustrates the anthropogenic pressure on earthworm communities in arable lands [90]. Similar report from Ivory Coast is available on the impact of land-use changes and landuse intensification on earthworm populations and diversity in intermediate-disturbed systems [91]. Even though these studies suggest the use of earthworms as bioindicators of man-made changes, it necessitates more field and laboratory investigations to find out earthworm community structure, species interrelations, and the most efficient species to be used in biomonitoring of ecosystem degradation due to anthropogenic activities in the forest areas.

Certain toxic substances in soil affect the behaviour and physiology of earthworms that can serve as biomonitoring tool for their systematic effect on soil organisms and other higher organisms. For example, the presence of tetra ethyl lead (TEL) in leaded gasoline and lead oxide has a significant effect on behaviour, morphology, and histopathology of earthworms. Absorption of TEL into the tissues of earthworms produced severe effects, rupture of the cuticle, extrusion of coelomic fluid, and inflexible metameric segmentation. This led to desensitization of the posterior region and its fragmentation [92].

The efficient potential of earthworms in bioaccumulation of heavy metals in their tissues serves as ecological indicator of soil contaminants. As per the recent report from India, the level of DTPA extractable metals in casts of earthworms, Metaphire posthuma (endogeic) and Lampito mauritii (anecic) collected from cultivated land, urban garden and sewage soils were higher than those of surrounding soil. The concentration of $\mathrm{Zn}, \mathrm{Fe}, \mathrm{Pb}$, and $\mathrm{Mn}$ in earthworm casts was higher in sewage soil followed by cultivated land and urban garden, respectively. There exists a close relationship between metal concentration in earthworm tissues and surrounding soils. The study also revealed the presence of species-specificity in metal accumulation in earthworms. Higher level of metal concentrating in the tissues was found in endogeic M. posthuma than in tissues of anecic L. mauritii. The difference in burrowing patterns may influence the patterns of bioaccumulations of metals apart from other contributory factors. Further, more detailed study is still required to elaborate the proposed hypothesis [93]. Analogous study conducted in Egypt also suggests that the variation in heavy metal concentration in soil and earthworms in different sites may be significant depending on soil properties and pollution status [88]. Sizmur and Hodson [94] evidently suggested that earthworms increase metal mobility and availability but more studies are required to determine the precise mechanism for this. So, this field of research with earthworm requires in depth research to understand the functional role of earthworms as bioindicators and bioconcentrators. 


\section{Earthworms and Vermicomposting: Indian Scenario}

The familiar earthworm species, Eudrilus eugeniae, Eisenia fetida, Lumbricus rubellus, and Perionyx excavatus, are well known for their efficiency in vermicomposting. It is desirable to know about other species of earthworms that may be as efficient or better in their performance over the above mentioned species in a country having rich diversity of fauna for in situ and ex situ vermiculture. There are more than a dozen of earthworm species that have been reported to be efficient in vermicomposting. Most of the species that are included under genus Perionyx show great potential to work on organic matter. Apart from the well-known P. excavatus, other Perionyx species such as $P$. ceylanensis, P. bainii, $P$. nainianus, and $P$. sansibaricus are recently considered to be the potential vermicomposting earthworms [20,95-97]. Future investigations provide scope for identifying more species with vermicomposting potential.

In natural systems, if earthworms are ecosystem engineers, in man made seminatural systems of organic residues, the detritivorous earthworms are saviors of biosphere from organic pollutants. From the review, it is very clear that the earthworm ecology needs much attention with reference to their functional role in different ecosystems. By the way of exploration, it might be possible to understand the significant role of earthworms in plant-microbe interactions. With regard to vermiculture, it is necessary to work on the idea of developing the consortia of earthworm species for vermiculture practices in India. It is always better to develop and encourage polycultures rather than maintaining monoculture. Moreover, with diversity in agricultural residues and by-products from agroindustries, it is essential to identify earthworms that will accept these materials with minimum effort and investment.

There are more than 500 species of earthworms distributed in different geographical regions in India, in different ecosystems. Being partly subtropical and partly temperate, majority of earthworms are endogeic or geophagous. Even among the epigeic earthworms (ca. 8\%), those that are voracious feeders, are efficient biomass producers, and have short life cycle, high rate of fecundity, and high rate of adaptability to changing physicochemical properties of feed material can only serve as successful species for vermiculture. One has to look for these characters before recommending any species for vermiculture. The species that is promising under protected laboratory conditions in a small scale may fail to perform under field conditions when it is expected to work on large amount of organic matter. The present scenario in India shows that there is good response from the farmers to adopt the technology for producing vermicompost to use as soil amendment. They are reaping the benefits of using the recommended species for producing required quantity of vermicompost to fulfill the needs of their land and also to market the production to other neighbourhood farmers. Still many avenues remain open for the scientists to carry out research in this field to unravel various problems associated with the technology.

\section{Acknowledgment}

The author, Dr. N. Karmegam, sincerely acknowledges the authorities of Gandhigram Rural University, Gandhigram for giving permission to publish part of his Ph.D. thesis.

\section{References}

[1] K. E. Lee, Earthworms: Their Ecology and Relationships with Soils and Land Use, Academic Press, Sydney, Australia, 1985.

[2] P. Lavelle, "The structure of earthworm communities," in Earthworm Ecology, J. E. Satchell, Ed., pp. 449-466, Chapman and Hall, London, UK, 1983.

[3] J. E. Satchell and D. G. Lowe, "Selection of leaf litter in Lumbricus terrestris," in Progress in Soil Biology, O. Graff and J. E. Satchell, Eds., pp. 102-119, North Holland, Amsterdam, The Netherlands, 1967.

[4] S. R. Ganihar, "Nutrient mineralization and leaf litter preference by the earthworm Pontoscolex corethrurus on iron ore mine wastes," Restoration Ecology, vol. 11, no. 4, pp. 475-482, 2003.

[5] R. D. Kale and R. V. Krishnamoorthy, "Litter preferences in the earthworm Lampito mauritii," Proceedings of Indian Academy Sciences, vol. 90, pp. 123-128, 1981.

[6] A. V. Tiunov and S. Scheu, "Carbon availability controls the growth of detritivores (Lumbricidae) and their effect on nitrogen mineralization," Oecologia, vol. 138, no. 1, pp. 83-90, 2004.

[7] M. C. Dash and V. C. Patra, "Density, biomass and energy budget of a tropical earthworm population from a grassland site in Orissa, India," Revue d Ecologie Et de Biologie du Sol, vol. 14, pp. 461-471, 1977.

[8] R. D. Kale and R. V. Krishnamoorthy, "Cyclic fluctuations and distribution of three species of tropical earthworms in a farmyard garden in Bangalore," Rev d' Ecolgie et de Biol du Sol, vol. 19, pp. 67-71, 1982.

[9] M. V. Reddy, V. P. K. Kumar, V. R. Reddy, et al., "Earthworm biomass response to soil management in semi-arid tropical Alfisol agroecosystems," Biology and Fertility of Soils, vol. 19, no. 4, pp. 317-321, 1995.

[10] G. Tripathi and P. Bhardwaj, "Seasonal changes in population of some selected earthworm species and soil nutrients in cultivated agroecosystem," Journal of Environmental Biology, vol. 25, no. 2, pp. 221-226, 2004.

[11] N. Karmegam and T. Daniel, "Effect of physico-chemical parameters on earthworm abundance: a quantitative approach," Journal of Applied Sciences Research, vol. 3, pp. 1369-1376, 2007.

[12] A. Sathianarayanan and A. B. Khan, "Diversity, distribution and abundance of earthworms in Pondicherry region," Tropical Ecology, vol. 47, no. 1, pp. 139-144, 2006.

[13] R. D. Kale, K. Bano, and R. V. Krishnamoorthy, "Anachoresis of earthworms," Bombay Natural History Society, vol. 78, pp. 400-402, 1981.

[14] S. Subler, C. M. Baranski, and C. A. Edwards, "Earthworm additions increased short-term nitrogen availability and leaching in two grain-crop agroecosystems," Soil Biology and Biochemistry, vol. 29, no. 3-4, pp. 413-421, 1997.

[15] C. H. Robinson, P. Ineson, T. G. Piearce, and A. P. Rowland, "Nitrogen mobilization by earthworms in limed peat soils under Picea sitchensis," Journal of Applied Ecology, vol. 29, no. 1, pp. 226-237, 1992. 
[16] C. A. Edwards and J. R. Lofty, "Nitrogenous fertilizers and earthworm populations in agricultural soils," Soil Biology and Biochemistry, vol. 14, no. 5, pp. 515-521, 1982.

[17] D. P. Knight, P. W. Elliott, J. M. Anderson, and D. Scholefield, "The role of earthworms in managed, permanent pastures in Devon, England," Soil Biology and Biochemistry, vol. 24, no. 12, pp. 1511-1517, 1992.

[18] M. J. Shipitalo and K. R. Butt, "Occupancy and geometrical properties of Lumbricus terrestris L. burrows affecting infiltration," Pedobiologia, vol. 43, no. 6, pp. 782-794, 1999.

[19] M. V. Reddy, V. R. Reddy, P. Balashouri, et al., "Responses of earthworm abundance and production of surface casts and their physico-chemical properties to soil management in relation to those of an undisturbed area on a semi-arid tropical alfisol," Soil Biology and Biochemistry, vol. 29, no. 3-4, pp. 617620, 1997.

[20] N. Karmegam and T. Daniel, "Selected physico-chemical characteristics and microbial populations of the casts of the earthworm, Pontoscolex corethrurus (Muller) and surrounding soil in an undisturbed forest floor in Sirumalai Hills, South India," Asian Journal of Microbiology, Biotechnology and Environmental Sciences, vol. 2, pp. 231-234, 2000.

[21] J. M. Julka, R. Paliwal, and P. Kathireswari, "Biodiversity of Indian earthworms-an overview," in Proceedings of IndoUS Workshop on Vermitechnology in Human Welfare, C. A. Edwards, R. Jayaraaj, and I. A. Jayraaj, Eds., pp. 36-56, Rohini Achagam, Coimbatore, India, 2009.

[22] N. Karmegam, Studies on earthworms, vermiculture, vermicomposting and utilization of vermicompost for plant growth, Ph.D. thesis, Gandhigram Rural University, Gandhigram, Tamil Nadu, India, 2002.

[23] N. Karmegam and T. Daniel, "A first report on the occurrence of a Megascolecid earthworm, Lampito kumiliensis (Annelida: Oligochaeta) in Sirumalai Hills of Tamil Nadu, South India," Ecology, Environment and Conservation, vol. 7, pp. 115-116, 2001.

[24] B. G. M. Jamieson, "Preliminary descriptions of Indian earthworms (Megascolecidae: Oligocaheta) from the Palni hills," Bullettin du Muséum National d'Histoire Naturelle Section A, vol. 313, pp. 478-502, 1977.

[25] S. A. Ismail and V. A. Murthy, "Distribution of earthworms in Madras," Proceedings of Indian Academy of Sciences (Animal Science), vol. 94, pp. 557-566, 1985.

[26] N. Karmegam and T. Daniel, "Abundance and population density of three species of earthworms (Annelida: Oligochaeta) in foothills of Sirumalai (Eastern Ghats), South India," Indian Journal of Environment and Ecoplanning, vol. 3, pp. 461-466, 2000.

[27] N. Karmegam and T. Daniel, "Population dynamics of a peregrine earthworm, Pontoscolex corethrurus in an undisturbed soil in Sirumalai Hills of Tamil Nadu, South India," Journal of Ecological Research and Bioconservation, vol. 1, pp. 9-14, 2000.

[28] T. Bhadauria and P. S. Ramakrishnan, "Population dynamics of earthworms and their activity in forest ecosystems of northeast India," Journal of Tropical Ecology, vol. 7, no. 3, pp. 305318, 1991.

[29] P. S. Chaudhuri and G. Bhattacharjee, "Earthworm resources of Tripura," Proceedings of National Academy of Sciences, India, vol. 69, pp. 159-170, 1999.

[30] C. A. Edwards and P. J. Bohlen, Biology and Ecology of Earthworms, Chapman \& Hall, London, UK, 1996.

[31] S. A. Ismail, "Earthworm resources of Madras," in Proceedings of National Seminar on Organic Waste Utilization and Vermi- composting, Part B: Verms and Vermicomposting, M. C. Dash, B. K. Senapati, and P. C. Mishra, Eds., pp. 8-15, 1986.

[32] K. Bano and R. D. Kale, "Earthworm fauna of Southern Karnataka, India," in Advances in Management and Conservation of Soil Fauna, G. K. Veeresh, D. Rajagopal, and C. A. Virakthamath, Eds., pp. 627-634, Oxford \& IBH, New Delhi, India, 1991.

[33] R. V. Krishnamoorthy, "Competition and coexistence in a tropical earthworm community in a farm garden near Bangalore," Journal of Soil Biology and Ecology, vol. 5, pp. 3347, 1985.

[34] T. Bhadauria and P. S. Ramakrishnan, "Earthworm population dynamics and contribution to nutrient cycling during cropping and fallow phases of shifting agriculture (jhum) in northeast India," Journal of Applied Ecology, vol. 26, no. 2, pp. 505520, 1989.

[35] S. A. Ismail, C. Ramakrishnan, and M. M. Anzar, "Density and diversity in relation to the distribution of earthworms in Madras," Proceedings of Indian Academy of Sciences, Animal Sciences, vol. 99, no. 1, pp. 73-78, 1990.

[36] B. R. Kaushal, S. P. S. Bisht, and S. Kalia, "Population dynamics of the earthworm Amynthas alexandri (Megascolecidae: Annelida) in cultivated soils of the Kumaun Himalayas," Applied Soil Ecology, vol. 2, no. 2, pp. 125-130, 1995.

[37] P. S. Chaudhuri, S. Nath, and R. Paliwal, "Earthworm population of rubber plantations (Hevea brasiliensis) in Tripura, India," Tropical Ecology, vol. 49, no. 2, pp. 225-234, 2008.

[38] A. V. Evans and W. J. Mc. L. Guild, "Studies on the relationships between earthworms and soil fertility. IV. On the life cycles of some British Lumbricidae," Annals of Applied Biology, vol. 35, pp. 471-484, 1948.

[39] B. K. Senapati and S. K. Sahu, "Population, biomass and secondary production in earthworms," in Earthworm Resources and Vermiculture, pp. 57-78, Zoological Survey of India, Calcutta, India, 1993.

[40] S. R. Ganihar, "Earthworm distribution with special reference to physicochemical parameters," Proceedings of Indian National Science Academy B, vol. 62, pp. 11-18, 1996.

[41] G. González, X. Zou, and S. Borges, "Earthworm abundance and species composition in abandoned tropical croplands: comparisons of tree plantations and secondary forests," Pedobiologia, vol. 40, no. 5, pp. 385-391, 1996.

[42] K. Auerswald, S. Weigand, M. Kainz, and C. Philipp, "Influence of soil properties on the population and activity of geophagous earthworms after five years of bare fallow," Biology and Fertility of Soils, vol. 23, no. 4, pp. 382-387, 1996.

[43] P. Lavelle, "Earthworm activities and the soil system," Biology and Fertility of Soils, vol. 6, no. 3, pp. 237-251, 1988.

[44] S. Nordström and S. Rundgren, "Environmental factors and Lumbricid associations in Southern Sweeden," Pedobiologia, vol. 13, pp. 301-326, 1974.

[45] B. K. Senapati and M. C. Dash, "Influence of soil temperature and moisture on the reproductive activity of tropical earthworms of Orissa," Journal of Soil Biology and Ecology, vol. 4, pp. 13-21, 1984.

[46] A. Kretzschmar and C. Bruchou, "Weight response to the soil water potential of the earthworm Aporrectodea longa," Biology and Fertility of Soils, vol. 12, no. 3, pp. 209-212, 1991.

[47] R. D. Kale and R. V. Krishnamoorthy, "Distribution and abundance of earthworms in Bangalore," Proceedings of Indian Academy of Sciences, vol. 88, pp. 23-25, 1978.

[48] C. Fragoso and P. Lavelle, "The earthworm community of a Mexican tropical rain forest (Chajul, Chiapas)," in On Earthworms, A. M. Bonvincini Paglai and P. Omodeo, Eds., 
Selected Symposia and Monographs U.Z.I., pp. 281-295, Modena, Mucchi, Italy, 1987.

[49] N. Joshi and S. Aga, "Diversity and distribution of earthworms in a subtropical forest ecosystem in Uttarakhand, India," The Natural History Journal of Chulalongkorn University, vol. 9, pp. 21-25, 2009.

[50] V. B. Tembe and P. J. Dubash, "The earthworms: a review," Journal of Bombay Natural History Society, vol. 58, pp. 171201, 1961.

[51] S. K. Roy, "Studies on the activities of earthworms," Proceedings of Zoological Society, Calcutta, vol. 10, pp. 81-98, 1957.

[52] G. E. Gates, "Ecology of some earthworms with special reference to seasonal activity," American Midland Naturalist, vol. 66, pp. 61-86, 1961.

[53] M. C. Dash and V. C. Patra, "Worm cast production and nitrogen contribution to soil by a tropical earthworm population from a grassland site from Orissa, India," Revue d Ecologie Et de Biologie du Sol, vol. 16, pp. 79-83, 1979.

[54] L. Norgrove and S. Hauser, "Effect of earthworm surface casts upon maize growth," Pedobiologia, vol. 43, no. 6, pp. 720-723, 1999.

[55] M. V. Reddy, "Annual cast production by the Megascolecid earthworm, Pheretima alexandri (Beddard)," Comparative Physiology and Ecology, vol. 8, pp. 84-86, 1983.

[56] P. Lavelle, "Les vers de terre de la savane de Lamto. Analyse d'un Ecosysteme tropical humide: LA Savanede Lamto (Côte d'Ivoire)," Bullettin De Liaison des chercheurs de Lamto, vol. 5, pp. 133-136, 1974.

[57] S. D. Nijhawan and J. S. Kanwar, "Physicochemical properties of earthworm castings and their effect on the productivity of the soil," Indian Journal of Agricultural Sciences, vol. 22, pp. 357-373, 1952.

[58] A. K. Dutt, "Earthworms and soil aggregation," Journal of American Society for Agronomy, vol. 48, p. 407, 1948.

[59] R. J. Swaby, "The influence of earthworm on soil aggregation," Journal of Soil Science, vol. 1, pp. 195-197, 1950.

[60] J. N. Parle, "A microbiological study of earthworm casts," Journal of General Microbiology, vol. 31, pp. 13-22, 1963.

[61] A. M. Habibullah and S. A. Ismail, "Preference to soil fractions and the effect of soil compaction on the casting and burrowing behaviour of the earthworm Lampito mauritii," Journal of Soil Biology and Ecology, vol. 5, pp. 26-32, 1985.

[62] G. W. Agarwal, K. S. K. Rao, and L. S. Negi, "Influence of certain species of earthworms on the structure of some hill soils," Current Science, vol. 27, p. 213, 1958.

[63] M. Puttarudraiah and K. S. S. Sastry, "A preliminary study of earthworm damage to crop growth," Mysore Agriculture Journal, vol. 36, pp. 2-11, 1961.

[64] P. M. Fraser, M. H. Beare, R. C. Butler, T. Harrison-Kirk, and J. E. Piercy, "Interactions between earthworms (Aporrectodea caliginosa), plants and crop residues for restoring properties of a degraded arable soil," Pedobiologia, vol. 47, no. 5-6, pp. 870-876, 2003.

[65] M. A. Callaham Jr. and P. F. Hendrix, "Impact of earthworms (Diplocardia: Megascolecidae) on cycling and uptake of nitrogen in coastal plain forest soils from northwest Florida, USA," Applied Soil Ecology, vol. 9, no. 1-3, pp. 233-239, 1998.

[66] S. A. Materechera, O. T. Mandiringana, and K. Nyamapfene, "Production and physico-chemical properties of surface casts from microchaetid earthworms in central Eastern Cape," South African Journal of Plant and Soil, vol. 15, no. 4, pp. 151$157,1998$.
[67] J. G. Shrikande and A. N. Pathak, "Earthworms and insects in relation to soil fertility," Current Science, vol. 17, pp. 327-328, 1948.

[68] N. V. Joshi and B. V. Kelkar, "Role of earthworms in soil fertility," Indian Journal of Agricultural Science, vol. 22, pp. 189-196, 1952.

[69] A. N. Ganeshamurthy, K. M. Manjaiah, and A. S. Rao, "Mobilization of nutrients in tropical soils through worm casting: availability of micronutrients," Soil Biology and Biochemistry, vol. 30, no. 13, pp. 1839-1840, 1998.

[70] R. D. Kale and R. V. Krishnamoorthy, "The calcium content of body tissues and castings of earthworm Pontoscolex corethrurus (Annelida-Oligochaeta)," Pedobiologia, vol. 20, pp. 309315,1980

[71] C. A. Edwards and N. Q. Arancon, "Interactions among organic matter, earthworms and microorganisms in promoting plant growth," in Soil Organic Matter in Sustainable Agriculture, pp. 327-376, 2004.

[72] J. V. Bhat, S. R. Khambata, G. B. Maya, C. A. Sastry, R. V. Iyer, and V. Iyer, "Effect of earthworms on the microflora of the soil," Indian Journal of Agricultural Science, vol. 30, no. 2, pp. 106-114, 1960.

[73] S. R. Khambata and J. V. Bhat, "A contribution to the study of the intestinal microflora of Indian earthworms," Archives of Microbiology, vol. 28, no. 1, pp. 69-80, 1957.

[74] M. C. Dash, P. C. Mishra, and N. Behara, "Fungal feeding by a tropical earthworm," Tropical Ecology, vol. 20, pp. 9-12, 1979.

[75] T. C. Dlamini, R. J. Haynes, and R. van Antwerpen, "Exotic earthworm species dominant in soils on sugarcane estates in the Eshowe area of the north coast of Kwazulu-Natal," in Proceedings of Annual Congress of South African Sugar Technologists Association, vol. 75, pp. 217-221, 2001.

[76] G. G. Brown, I. Barois, and P. Lavelle, "Regulation of soil organic matter dynamics and microbial activity in the drilosphere and the role of interactions with other edaphic functional domains," European Journal of Soil Biology, vol. 36, no. 3-4, pp. 177-198, 2000.

[77] A. Kretzschmar, "Importance of the interaction of soil fauna and microflora for formation of humus and development of organic substance," Berichte uber Landwirtschaft son der heft, vol. 206, pp. 117-126, 1992.

[78] T. Bhatnagar, "Lombriciens et humification: un aspect nouveau de l'incorporation microbienne d'azote induite par les vers de terre," in Biodegradation et Humification, pp. 169-182, Pierron, Satreguemines, France, 1975.

[79] J. V. Bhat, "Suitability of experimentation diets for earthworm culture," Current Science, vol. 43, pp. 266-268, 1974.

[80] R. D. Kale, K. Vinayaka, K. Bano, and D. J. Bagyaraj, "Suitability of neem cake as an additive in earthworm fed and its influence on the establishment of microflora," Journal of Soil Biology and Ecology, vol. 6, pp. 98-103, 1986.

[81] R. Nagar, N. Joshi, S. Dwivedi, and V. K. Khaddar, "A physicochemical and micofloral profile of vermicompost in Tarai region of Himalaya in winter season," Research on Crops, vol. 5, pp. 51-54, 2004.

[82] K. Parthasarathi, L. S. Ranganathan, and J. Zeyer, "Species specific predation of fungi by Lampito mauritii (Kinb) and Eudrilus eugeniae (Kinb) reared on press mud," in Session 3. Earthworms and Vermicomposting, D. J. Bagyaraj, Ed., VII National Symposium on Soil Biology and Ecology, Ab, p. 69, 2001.

[83] B. S. Rajani, D. Radhakrishna, V. R. Ramakrishnaparama, R. D. Kale, and A. N. Balakrishna, "Influence of vermicomposting of urban solid wastes on microbial density and enzyme 
activities," in Session 4, Soil Biota as Bioindicators of Soil Health, D. J. Bagyaraj, Ed., VII National Symposium on Soil Biology and Ecology, Ab, p. 69, 2001.

[84] B. Raghavendra Rao, Assessment of microbial and biochemical quality of urban compost and its impact on soil health, Ph.D. thesis, University of Agricultural Sciences, Bangalore, India, 2001.

[85] M. Prakash, M. Jayakumar, and N. Karmegam, "Physicochemical characteristics and fungal flora in the casts of the earthworm, Perionyx ceylanensis Mich. reared in Polyalthia longifolia leaf litter," Journal of Applied Sciences Research, vol. 4, pp. 53-57, 2008.

[86] M. Jayakumar, V. Karthikeyan, and N. Karmegam, "Comparative studies on physico-chemical, microbiological and enzymatic activities of vermicasts of the earthworms, Eudrilus eugeniae, Lampito mauritii and Perionyx ceylanensis cultured in press mud," International Journal of Applied Agricultural Research, vol. 4, pp. 75-85, 2009.

[87] J. J. Hinton and M. M. Veiga, "Earthworms as bioindicators of mercury pollution from mining and other industrial activities," Geochemistry: Exploration, Environment, Analysis, vol. 2, no. 3, pp. 269-274, 2002.

[88] H. M. Mahmoud, "Earthworm (Lumbricus terrestris) as indicator of heavy metals in soils," Online Journal of Veterinary Research, vol. 11, pp. 23-37, 2008.

[89] C. B. Iwai, P. Yupin, and B. N. Noller, "Earthworm: potential bioindicator for monitoring diffuse pollution by agrochemical residues in Thailand," KKU Research Journal, vol. 139, pp. 1081-1088, 2008.

[90] S. Suthar, "Earthworm communities as bioindicator of arable land management practices: a case study in semiarid region of India," Ecological Indicators, vol. 9, no. 3, pp. 588-594, 2009.

[91] J. E. Tondoh, L. M. Monin, S. Tiho, and C. Csuzdi, "Can earthworms be used as bio-indicators of land-use perturbations in semi-deciduous forest?" Biology and Fertility of Soils, vol. 43, no. 5, pp. 585-592, 2007.

[92] J. Venkateswara Rao, P. Kavitha, and A. Padmanabha Rao, "Comparative toxicity of tetra ethyl lead and lead oxide to earthworms, Eisenia fetida (Savigny)," Environmental Research, vol. 92, no. 3, pp. 271-276, 2003.

[93] S. Suthar, S. Singh, and S. Dhawan, "Earthworms as bioindicator of metals $(\mathrm{Zn}, \mathrm{Fe}, \mathrm{Mn}, \mathrm{Cu}, \mathrm{Pb}$ and $\mathrm{Cd})$ in soils: is metal bioaccumulation affected by their ecological category?" Ecological Engineering, vol. 32, no. 2, pp. 99-107, 2008.

[94] T. Sizmur and M. E. Hodson, "Do earthworms impact metal mobility and availability in soil?-a review," Environmental Pollution, vol. 157, no. 7, pp. 1981-1989, 2009.

[95] S. Suthar, "Growth and fecundity of earthworms: Perionyx excavatus and Perionyx sansibaricus in cattle waste solids," The Environmentalist, vol. 29, no. 1, pp. 78-84, 2009.

[96] N. Karmegam and T. Daniel, "Investigating efficiency of Lampito mauritii (Kinberg) and Perionyx ceylanensis Michaelsen for vermicomposting of different types of organic substrates," The Environmentalist, vol. 29, no. 3, pp. 287-300, 2009.

[97] N. Karmegam and T. Daniel, "Growth, reproductive biology and life cycle of the vermicomposting earthworm, Perionyx ceylanensis Mich. (Oligochaeta: Megascolecidae)," Bioresource Technology, vol. 100, no. 20, pp. 4790-4796, 2009. 

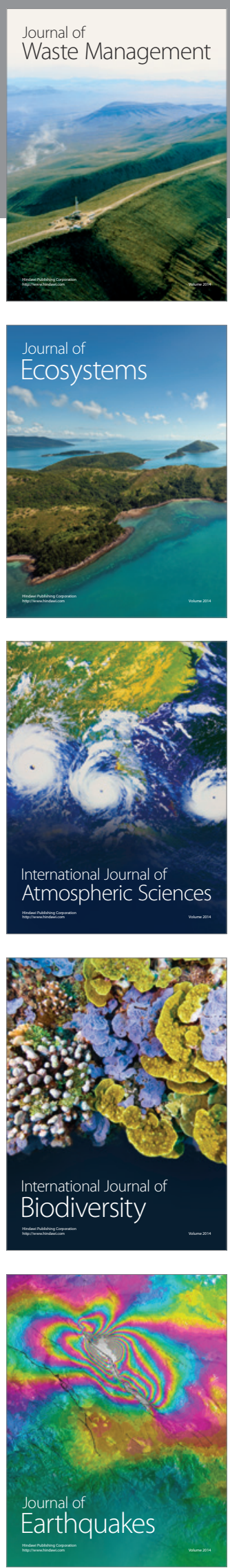
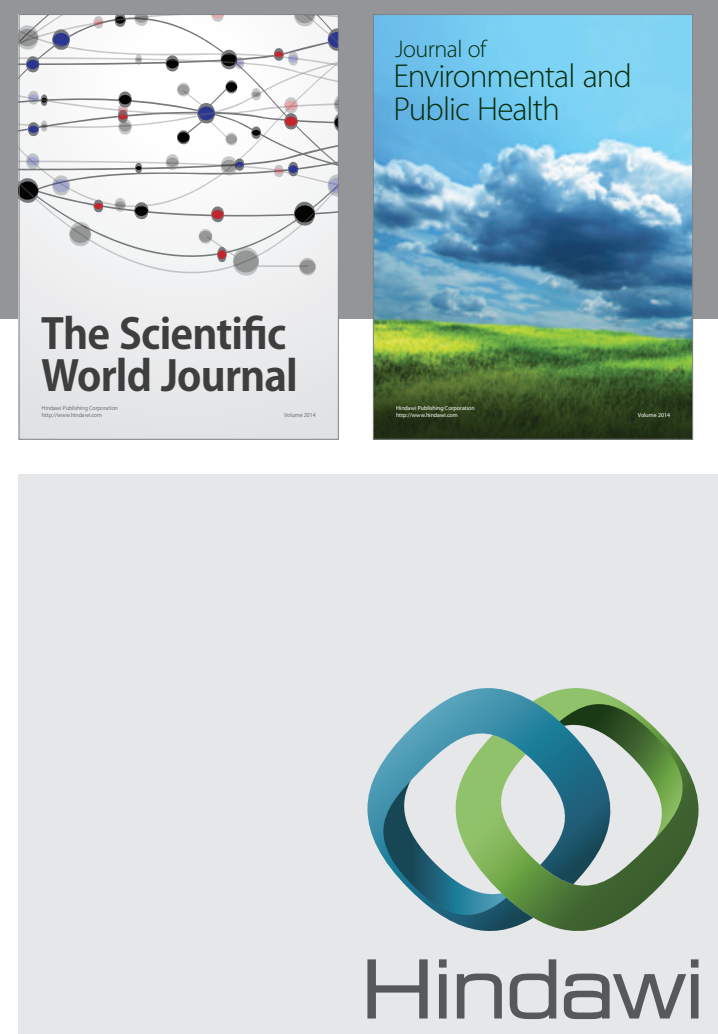

Submit your manuscripts at

http://www.hindawi.com
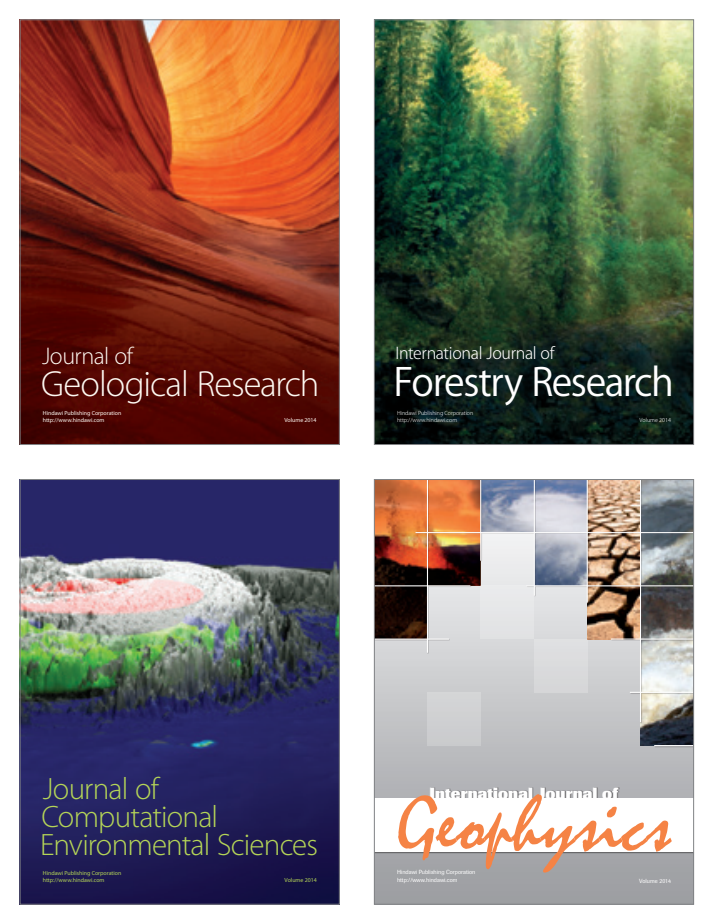
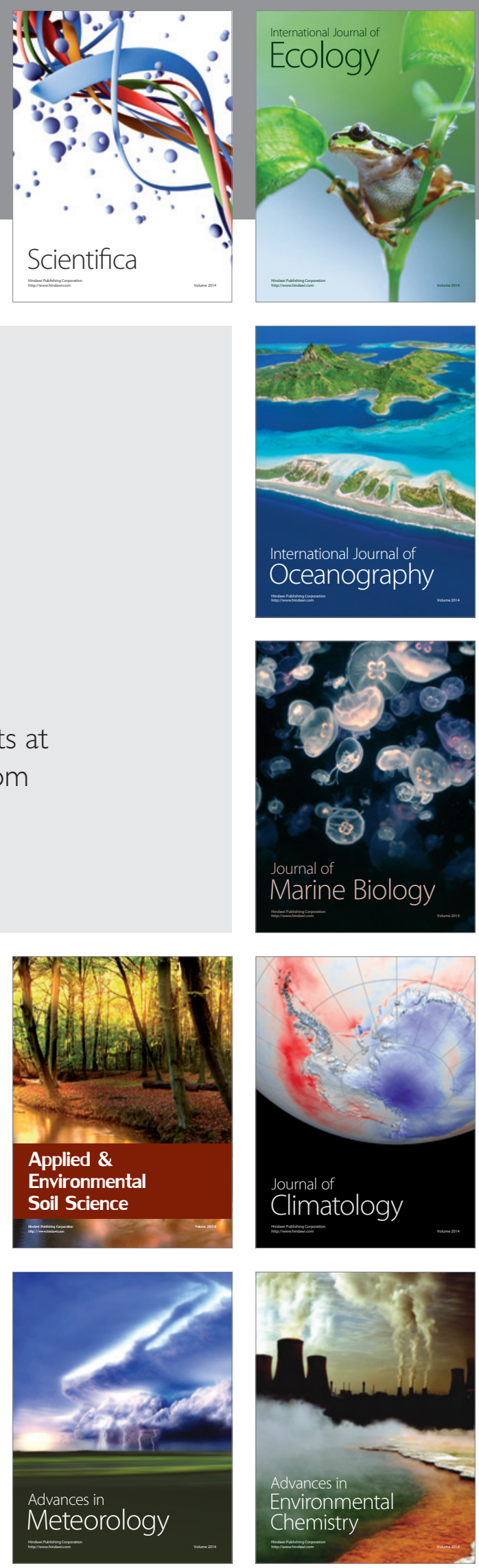